\title{
ZAGADNIENIE TZW. DOMÓW KULTOWYCH W MEGALITYCZNYM OBRZĄDKU POGRZEBOWYM LUDNOŚCI KULTURY PUCHARÓW LEJKOWATYCH W POLSCE ${ }^{1}$
}

\section{SO-CALLED CULT HOUSES IN MEGALITHIC TRADITIONS OF THE FUNNELBEAKER CULTURE IN POLAND}

\author{
Krzysztof Socha \\ Muzeum Twierdzy Kostrzyn \\ ul. Graniczna 1, 66-470 Kostrzyn nad Odrą \\ Krzysztof.socha@muzeum.kostrzyn.pl
}

\begin{abstract}
The article is a summary of the state of the art concerning the so-called cult houses discovered in megaliths of the Funnel Beaker culture (hereinafter referred to as TRB from German Trichterbecherkultur) in its Eastern and South-Eastern groups.

The author suggests to divide the discussed objects into types "A" and "B", which may better reflect their characteristics. He also emphasises that the reinterpretation of some of the known features as the structures of this type would significantly increase their number. If the chosen course of interpretation appears accurate, it may indicate that the presence of wooden structures in the TRB graves in the Polish lands was not at all special. However, it should be borne in mind that these objects might have served not only for religious purposes.
\end{abstract}

KEY WORDS: cult houses, Funnel Beaker culture, megalithic burial practices, megaliths.

\section{WSTEPP}

Na określenie budowli drewnianych odkrywanych w grobowcach megalitycznych ludności kultury pucharów lejkowatych (dalej KPL) jest znanych z literatury

\footnotetext{
${ }^{1}$ Niniejszy tekst jest skróconą i zmodyfikowaną wersją mojej pracy magisterskiej pt. Problem wykorzystania drewna w megalitycznym obrzadku pogrzebowym spoteczności kultury pucharów lejkowatych, napisanej pod kierunkiem Szanownej Jubilatki, Pani Profesor Dobrochny Jankowskiej, i obronionej we wrześniu 2008 r. w Instytucie Prahistorii Uniwersytetu im. Adama Mickiewicza w Poznaniu. W tym miejscu bardzo serdecznie dziękuję Pani Profesor za pomoc i cenne uwagi przy pisaniu niniejszej pracy. Podziękowania za wskazówki dotyczące poniższego tekstu składam także dr. Markowi Florkowi. Tekst pierwotnie miał być opublikowany w roczniku Archeologia Polski Środkowowschodniej, lecz ze względu na zawieszenie czasopisma nigdy to nie nastąpiło.
} 
przedmiotu kilka terminów. Wśród nich należy wymienić: budowle kultowe, domy bądź domki kultowe, świątynie, sanktuaria, kaplice, konstrukcje drewniane czy wreszcie chaty kultowe (m.in. Chmielewski 1952; Gorczyca 1981; Krzak 1994; Madsen 1979; Midgley 1985; Rzepecki 2011; Wierzbicki 2006, 2008; Zych 2002, 2006).

Nazwy te sugerują bezsprzecznie „kultowy” bądź „,ceremonialny” charakter omawianych konstrukcji. Trzeba jednak zauważyć, iż obiekty te także mogły pełnić inne funkcje. W niniejszym tekście używany będzie termin dom kultowy. Moim zdaniem najlepiej oddaje on charakter, cechy konstrukcyjne i funkcję omawianych założeń.

Podstawowym celem niniejszego artykułu jest zebranie i przedstawienie „domów kultowych" zarejestrowanych w grobowcach megalitycznych ludności KPL. Ponadto podjęta została próba innego ich podziału, a także nowej interpretacji tych obiektów.

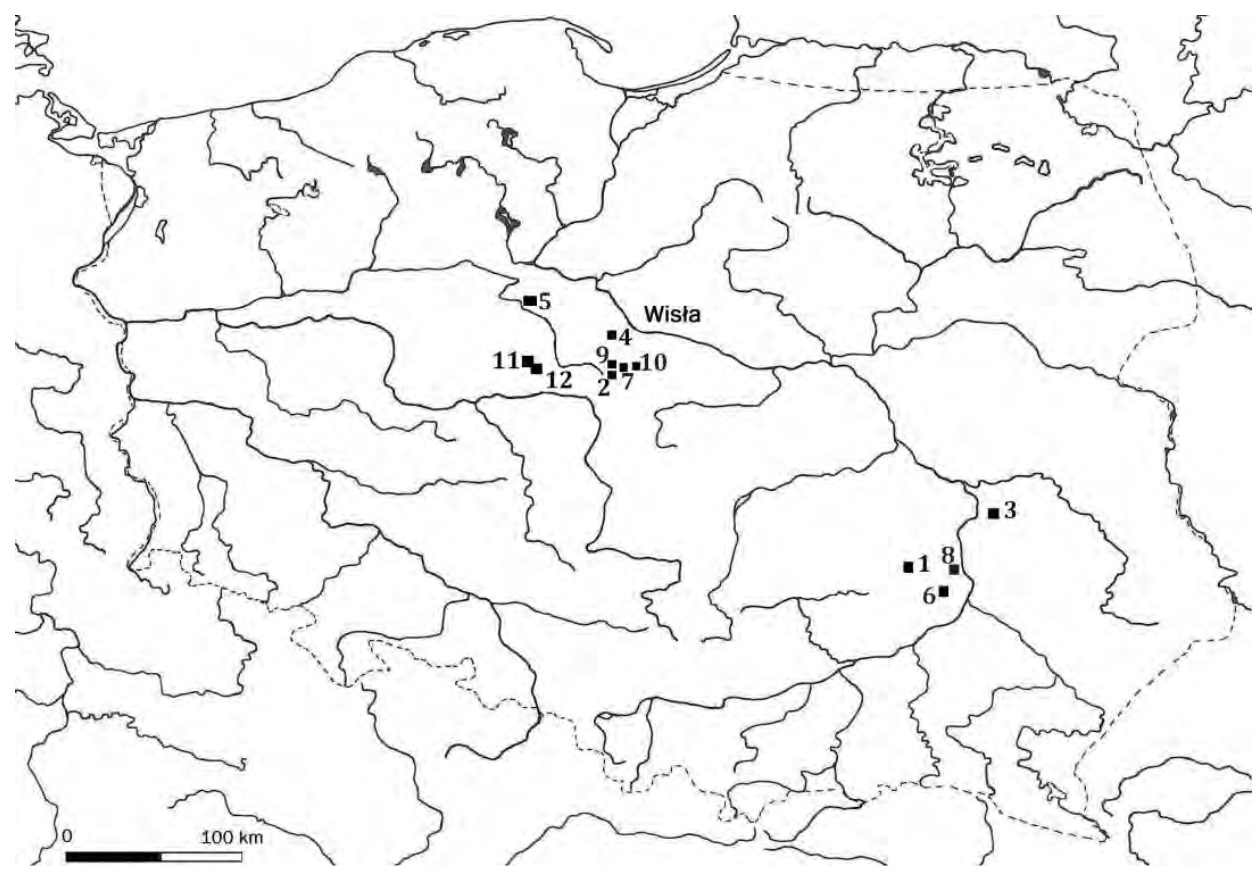

Ryc. 1. „Domy kultowe” w grobowcach megalitycznych społeczności KPL na ziemiach polskich: 1 - Broniszowice, stan. 5; 2 - Gaj, stan. 1; 3 - Karmanowice, stan. 35; 4 - Leśniczówka, stan. 1; 5 - Łącko, stan. 6-6A; 6 - Malice Kościelne, stan. 1; 7 - Obałki, stan. 1; 8 - Pawłów, stan. 3; 9 - Sarnowo, stan. 1; 10 - Wietrzychowice, stan. 1; 11 - Zberzyn, stan. 3;12 - Zberzynek, stan. 4 (oprac. Krzysztof Socha)

Fig. 1. Cult houses within megaliths of the TRB communities in Poland: 1 - Broniszowice, site 5; 2 - Gaj, site 1; 3 - Karmanowice, site 35; 4 - Leśniczówka, site 1; 5 - Łącko, sites 6-6A; 6 - Malice Kościelne, site 1; 7 - Obałki, site 1; 8 - Pawłów, site 3;9 - Sarnowo, site 1;10 - Wietrzychowice, site 1;

11 - Zberzyn, site 3; 12 - Zberzynek, site 4 (by Krzysztof Socha) 
Ramy chronologiczne pracy obejmują okres od początków fazy sarnowskiej (A/B) na Kujawach (Rzepecki 2004, s. 98, tab. 18; Wiklak 1982, s. 65) do momentu transformacji i zaniku grupy łupawskiej (Wierzbicki 1999, s. 11). Dobrochna Jankowska (2005, s. 138) twierdzi, że „[...] chronologia grobowców kujawskich w świetle najnowszych szacunków zamyka się w obrębie wczesnych faz KPL (faza I?-IIIa/IIIb? wg A. Kośko), to znaczy między ok. 3500-2800 p.n.e.”. Ta sama autorka chronologię pomorskich grobowców bezkomorowych ustala na okres między 3250 a 2700 p.n.e. (Jankowska 2005, s. 136). Te ustalenia chronologiczne mogą zostać zweryfikowane i zmienione w wyniku nowych prac archeologicznych oraz wyników analiz specjalistycznych z badań już zakończonych.

Zakres przestrzenny poniższych rozważań został ograniczony do obszaru ziem polskich. Omawiane konstrukcje były stosowane w obrządku pogrzebowym ludności grupy wschodniej i grupy południowo-wschodniej KPL (ryc. 1). Przy ich interpretacji uwzględniono także analogie z obszarów ościennych (grupa południowa i północna KPL).

\section{HISTORIA BADAŃ}

Ze starszej literatury przedmiotu znanych jest kilka dobrze rozpoznanych obiektów megalitycznych z konstrukcjami drewnianymi, pochodzących z obszarów Niżu: Gaj, pow. kolski; Obałki, pow. włocławski (Chmielewski 1952, s. 83-92); Sarnowo, pow. włocławski (Wiklak 1975); Zberzyn, pow. koniński (Gorczyca 1981). W trakcie badań przedwojennych początkowo nie zwracano jednak uwagi na tego typu konstrukcje; badania obejmowały zwykle tylko grób centralny i jego najbliższą okolicę (Chmielewski 1952; np. badania von Eckerta). Można zatem zakładać, że część $\mathrm{z}$ istniejących tego rodzaju obiektów została przeoczona podczas amatorskich wykopalisk. Później zapewne uległy one zniszczeniu (Chmielewski 1952, s. 9-10).

Dopiero badania Konrada Jażdżewskiego (1936a, s. 172-182) w Leśniczówce, pow. włocławski, w trakcie których zarejestrował „warstwy ogniskowe”, rzuciły trochę światła na ten aspekt obrządku pogrzebowego ludności KPL. Jednak odkrycie tych obiektów spotkało się z dużymi problemami interpretacyjnymi. Waldemar Chmielewski $(1952$, s. 19, 79) na ich określenie zamiennie używa terminów „śmietnisko-ognisko" i „warstwa ogniskowa”. W innym tonie wypowiada się Magdalena S. Midgley. Twierdzi ona, że obiekty zarejestrowane w grobowcach megalitycznych w Leśniczówce zostały wzniesione specjalnie na potrzeby zabiegów obrzędowo-sakralnych związanych z pogrzebaniem zmarłego/zmarłej. Nie ma także żadnych przesłanek, aby konstrukcje te uznawać za ślady wcześniejszego osadnictwa (Midgley 1985, s. 160-161). Za taką interpretacją wspomnianych powyżej obiektów opowiada się także autor niniejszego tekstu. Na podstawie ich rozmiaru, kształtu 
i lokalizacji wewnątrz grobowca, tuż za jego podstawą, można przypuszczać, że są to pozostałości „domów kultowych”.

Podobne problemy interpretacyjne dotyczą konstrukcji z Karmanowic, pow. puławski (Nogaj-Chachaj 1991, s. 628-640; 1997, s. 16-23; 1998, s. 30-35), Sarnowa (Gabałówna 1968, s. 136; Wiklak 1982, s. 61-63; Niesiołowska-Śreniowska 1982, s. 111-112), Wietrzychowic, pow. włocławski (Jażdżewski 1936b, s. 121-129; Jadczykowa 1970, 1972, s. 98-99) i Zberzynka, pow. koniński (Tetzlaff 1961, s. 40-47). Wymienione obiekty należy jednak uwzględnić przy rozważaniach nad obecnością „domów kultowych” w megalitycznym obrządku pogrzebowym ludności KPL.

Dzisiaj prawdopodobieństwo odkrycia „domów kultowych” jest znacznie większe dzięki nowszym metodom badawczym oraz wyczuleniu archeologów na obecność tego typu konstrukcji w grobowcach. Takie budowle zarejestrowano podczas badań w Broniszowicach, pow. ostrowiecki, w Łącku, pow. inowrocławski, w Malicach Kościelnych, pow. opatowski czy Pawłowie, pow. sandomierski (Bargieł, Florek 2005, s. 23-25, 2006a, s. 365-367, 372, 2006b, s. 385-391; Bargieł, Florek, Libera 1999, ryc. 2; Bąbel 2006, s. 273, 280, 283; Domańska 2006, s. 297; Rzepecki 2004, s. 124-128). Pozostałości po budowli o konstrukcji żerdziowej (?) miały zostać zarejestrowane podczas wykopalisk prowadzonych w Muszkowicach, pow. ząbkowicki (Cholewa, Wojciechowski, Limisiewicz 2003, 2004). Kolejne sezony wykopaliskowe zweryfikowały jednak tę hipotezę. Obecnie omawiany obiekt interpretowany jest jako pozostałość po neolitycznej orce ${ }^{2}$.

\section{STAN BADAŃ NAD „DOMAMI KULTOWYMI”}

Mimo 20 rozpoznanych budowli tego rodzaju (tab. 1) stan badań nad nimi nie jest zadowalający. Należy zastanowić się nad ich genezą, chronologią, a także nad zagadnieniem ich funkcji.

Do tej pory jednym z niewielu tekstów szczegółowo poruszających problem „domów kultowych” w megalitycznym obrządku pogrzebowym ludności KPL był artykuł Krzysztofa Gorczycy (1981). W omawianej pracy autor podsumował wyniki badań w Zberzynie, m.in. przedstawiając odkrytą podczas badań budowlę, jej cechy konstrukcyjne, a także proces budowy całego grobowca. Ponadto zastosował podział „chat kultowych” (tak określił ten rodzaj budowli) - ze względu na ich konstrukcję na dwa typy: typ Gaj oraz typ Sarnowo, z tym że swoją uwagę skupił tylko na „chatach typu Gaj”. Jak zauważa K. Gorczyca (1981, s. 16), praktyka budowania domu dla zmarłego była powszechnie stosowana na obszarze grupy północnej i zachodniej KPL (Konsens Høj, Troelstrup). Twierdzi również, że społeczeństwa wczesnej (A/B)

\footnotetext{
${ }^{2}$ Informacje ustne dr Agnieszki Przybył z Instytutu Archeologii Uniwersytetu Wrocławskiego, za które serdecznie dziękuje.
} 
Tabela 1. „Domy kultowe” w grobowcach megalitycznych społeczności kultury pucharów lejkowatych na ziemiach polskich

Table 1. Cult houses in megaliths of TRB in Poland

\begin{tabular}{|c|c|c|c|c|c|c|}
\hline L.p. & $\begin{array}{l}\text { Miejscowość, } \\
\text { nr stanowiska }\end{array}$ & $\begin{array}{l}\text { Numer } \\
\text { obiektu }\end{array}$ & $\begin{array}{l}\text { Typ domu } \\
\text { kultowego }\end{array}$ & Datowanie & Literatura & Uwagi \\
\hline 1 & $\begin{array}{l}\text { Broniszowice, } \\
\text { stan. 5A }\end{array}$ & - & ,A” & - & $\begin{array}{l}\text { Bąbel 2006, s. 273, } \\
281,284\end{array}$ & atypowa konstrukcja budowli \\
\hline 2 & $\begin{array}{l}\text { Gaj, } \\
\text { stan. } 1\end{array}$ & 1 & ,A” & - & $\begin{array}{l}\text { Chmielewski 1952, } \\
\text { s. 86-92, ryc. 49-60 }\end{array}$ & Budowla uległa spaleniu. \\
\hline 3 & $\begin{array}{l}\text { Karmanowice, } \\
\text { stan. } 35\end{array}$ & $\mathrm{~V} / 96$ & $\begin{array}{l}\text { hipotetycz- } \\
\text { ny ,dom”" }\end{array}$ & - & $\begin{array}{l}\text { Nogaj-Chachaj 1997, } \\
\text { s. 16-23; 1998, s. 30-35 }\end{array}$ & stanowisko wielokulturowe \\
\hline \multirow{3}{*}{4} & \multirow{3}{*}{$\begin{array}{l}\text { Leśniczówka, } \\
\text { stan. } 1\end{array}$} & 1 & „dom”(?) & \multirow{3}{*}{-} & \multirow{3}{*}{$\begin{array}{l}\text { Jażdżewski 1936a, } \\
\text { s. 172-182; Chmielew- } \\
\text { ski 1952, s. 73-80 }\end{array}$} & \multirow{3}{*}{$\begin{array}{l}\text { reinterpretacja obiektów; praw- } \\
\text { dopodobnie uległy one spale- } \\
\text { niu }\end{array}$} \\
\hline & & 2 & ,B” & & & \\
\hline & & 3 & „B” & & & \\
\hline 5 & $\begin{array}{l}\text { Łącko, } \\
\text { stan. 6-6A }\end{array}$ & 2 & „B” & $\begin{array}{l}5010 \pm 70 \mathrm{BP} \\
3820 \pm 90 \mathrm{BC}\end{array}$ & $\begin{array}{l}\text { Domańska } 1995, \\
\text { s. 8-10; 2006, } \\
\text { s. 289-298; Rzepecki } \\
\text { 2004, s. 124-128 }\end{array}$ & Konstrukcja uległa pożarowi. \\
\hline \multirow[b]{2}{*}{6} & \multirow{2}{*}{$\begin{array}{l}\text { Malice } \\
\text { Kościelne, } \\
\text { stan. 1 }\end{array}$} & 1 & ,B” & \multirow[b]{2}{*}{-} & \multirow{2}{*}{$\begin{array}{l}\text { Bargieł, Florek 2006a, } \\
\text { s. 361-384 }\end{array}$} & brak śladów pożaru \\
\hline & & 2 & „B” (?) & & & $\begin{array}{l}\text { E - część grobowca; obiekt } \\
\text { bardzo zniszczony }\end{array}$ \\
\hline 7 & $\begin{array}{l}\text { Obałki, } \\
\text { stan. } 1\end{array}$ & 2 & ,A" & - & $\begin{array}{l}\text { Chmielewski } 1952, \\
\text { s. } 83-86, \text { ryc. } 44-48 ; \\
\text { Tetzlaff } 1961, \text { s. } 40-47\end{array}$ & $\begin{array}{l}\text { Konstrukcja prawdopodobnie } \\
\text { uległa pożarowi. }\end{array}$ \\
\hline \multirow{3}{*}{8} & \multirow{3}{*}{$\begin{array}{l}\text { Pawłów, } \\
\text { stan. } 3\end{array}$} & megalit & ,A” & \multirow{3}{*}{-} & \multirow{3}{*}{$\begin{array}{l}\text { Bargiel, Florek 2005, } \\
\text { s. } 23-25 ; 2006 \text { b, } \\
\text { s. } 385-400\end{array}$} & \multirow{3}{*}{$\begin{array}{l}\text { brak śladów pożaru w obiek- } \\
\text { tach }\end{array}$} \\
\hline & & $\begin{array}{l}\text { „podkowiasty } \\
\text { rów” }\end{array}$ & ,A" & & & \\
\hline & & $\begin{array}{l}\text { budowla } \\
\text { słupowa }\end{array}$ & „B” & & & \\
\hline \multirow[t]{2}{*}{9} & \multirow[t]{2}{*}{$\begin{array}{l}\text { Sarnowo, } \\
\text { stan. } 1\end{array}$} & 8 & „B” (?) & - & $\begin{array}{l}\text { Gabałówna 1968, } \\
\text { s. 136; Wiklak 1982, } \\
\text { s. } 61-63\end{array}$ & $\begin{array}{l}\text { Dom prawdopodobnie uległ } \\
\text { pożarowi. } \\
\text { Data radiowęglowa }(5570 \pm 60 \\
\text { BP), } 4410 \pm 50 \text { BC uzyskana } \\
\text { dla jamy nr } 1 \text { spod grobowca } 8 \\
\text { w Sarnowie, pow. włocławski. } \\
\text { Do uzyskanej daty należy się } \\
\text { jednak odnosić z dystansem. }\end{array}$ \\
\hline & & 9 & „B” & - & $\begin{array}{l}\text { Wiklak 1975, s. 43-53; } \\
\text { 1986, s. 167-191 }\end{array}$ & $\begin{array}{l}\text { dom kultowy z tzw. przybu- } \\
\text { dówką }\end{array}$ \\
\hline \multirow{2}{*}{10} & \multirow{2}{*}{$\begin{array}{l}\text { Wietrzycho- } \\
\text { wice, stan. } 1\end{array}$} & 3 & „B” (?) & - & \multirow{2}{*}{$\begin{array}{l}\text { Jadczykowa } 1970 \text {, } \\
\text { s. } 134-135 ; 1972, \\
\text { s. } 101\end{array}$} & \multirow{2}{*}{$\begin{array}{l}\text { Dla grobowca } 2 \text { uzyskano datę } \\
5180 \pm 185 \mathrm{BP}, 4000 \pm 210 \mathrm{BC} \text {; } \\
\text { datuje ona orientacyjnie całe } \\
\text { cmentarzysko. }\end{array}$} \\
\hline & & 5 & ,B” & - & & \\
\hline \multirow{2}{*}{11} & \multirow{2}{*}{$\begin{array}{l}\text { Zberzyn, } \\
\text { stan. } 1\end{array}$} & 1 & ,A" & $\begin{array}{l}4620 \pm 40 \mathrm{BP} \\
3429 \pm 61 \mathrm{BC}\end{array}$ & Gorczyca 2007 & \multirow{2}{*}{$\begin{array}{l}\text { Wyniki badań grobowca I są } \\
\text { w trakcie opracowywania; oba } \\
\text { domy uległy pożarowi. }\end{array}$} \\
\hline & & 4 & ,A” & $\begin{array}{l}4720 \pm 110 \mathrm{BP} \\
3495 \pm 119 \mathrm{BC}\end{array}$ & Gorczyca 1981 , s. 1-20 & \\
\hline 12 & $\begin{array}{l}\text { Zberzynek, } \\
\text { stan. } 4\end{array}$ & - & „dom” (?) & - & Tetzlaff 1961, s. 40-42 & $\begin{array}{l}\text { Budowla została prawdopo- } \\
\text { dobnie spalona. }\end{array}$ \\
\hline
\end{tabular}


fazy KPL przejęły trapezowate formy budownictwa od społeczeństw „,wstęgowych”. Uważa je za wyjściowe formy dla budowanych domów zmarłych - grobowców bezkomorowych (np. konstrukcja z Łącka). Proces kształtowania się form tych grobowców miał przebiegać w dwóch etapach: faza I - wierne odwzorowanie szałasu, faza II - megalityzacja (Kośko 1976, s. 406). Na tej podstawie K. Gorczyca (1981, s. 16) wysunął wniosek, że

[...] grobowce $\mathrm{z}$ dodatkową budowlą typu Gaj [...] należałoby interpretować jako przejaw dalszej sakralizacji grobowca powstałej na tle komplikowania się reguł kultu. Natomiast budowle typu Sarnowo byłyby wyrazem wcześniejszych poszukiwań w kierunku rozwiązań formalnych tej idei. [...] Logicznym następstwem tego procesu było przypuszczalnie oddzielenie się budowli kultowej od grobowca.

Podobnego podziału tych obiektów z terenu Kujaw i części Wielkopolski dokonał Seweryn Rzepecki (2004, s. 127). Autor ten twierdzi, iż w odniesieniu do stanowisk wymienianych niekiedy w kontekście tzw. budowli kultowych konieczna jest daleko idąca ostrożność.

\section{PODZIAL „DOMÓW KULTOWYCH”}

Wszystkie „domy kultowe” omawiane w niniejszym tekście zlokalizowane są wewnątrz megalitów ludności kultury pucharów lejkowatych. Biorąc pod uwagę umiejscowienie „domów” w stosunku do pochówków wewnątrz grobowców megalitycznych, można je podzielić na trzy rodzaje:

- „domy kultowe typu A” - nienakrywające grobu (grobów) ludności KPL;

- ,domy kultowe typu B” - usytuowane nad grobem (grobami) ludności KPL;

- hipotetyczne „domy kultowe” - obiekty, które prawdopodobnie są pozostałościami tych budowli, jednak bez możliwości bliższego określenia ich typu.

Do tych wymienionych kategorii zostały zaklasyfikowane budowle o konstrukcji drewnianej, a także takie, co do których istnieje uzasadnione przypuszczenie, że drewno zostało użyte do wzniesienia tych obiektów. W przedstawionym powyżej opisie trzech typów uwzględniony został podział „,chat kultowych” wg K. Gorczycy (1981), oparty na szczegółach konstrukcyjnych. Należy jednak w tym miejscu zaznaczyć, iż nie ma zauważalnych wyraźnych zależności między lokalizacją „domów" a ich cechami konstrukcyjnymi. Poszczególne budowle wykazują duże różnice pod kątem techniki wykonania (konstrukcje: sumikowo-łątkowa i zrębowa). Natomiast w starszych badaniach brakuje często danych dotyczących sposobu ich budowy (por. Chmielewski 1952). 


\section{„DOMY KULTOWE TYPU A”}

Do tej grupy zaliczono siedem „domów” (tab. 1). Ich cechą wspólną jest lokalizacja w czołowej, zazwyczaj wschodniej - szerszej części grobowca. Omawiane konstrukcje nie „nakrywają” grobu/grobów ludności KPL. Poniżej przedstawiono krótką charakterystykę ,domów kultowych typu A”.

We wschodniej części grobowca w Broniszowicach odkryto ślady po konstrukcji słupowej w postaci 13 dołków posłupowych. Ich średnice wynosiły $0,15-0,33 \mathrm{~m}$, miały zaokrąglone dno. Miąższość poszczególnych dołków wahała się od 0,08 do $0,34 \mathrm{~m}$. Jest to konstrukcja $\mathrm{w}$ kształcie prostokąta o wymiarach $4 \times 2 \mathrm{~m}$. Wewnątrz niej odkryto ślady ogniska. Do środka budowli wchodziło się od strony wschodniej (Bąbel 2006, s. 273).

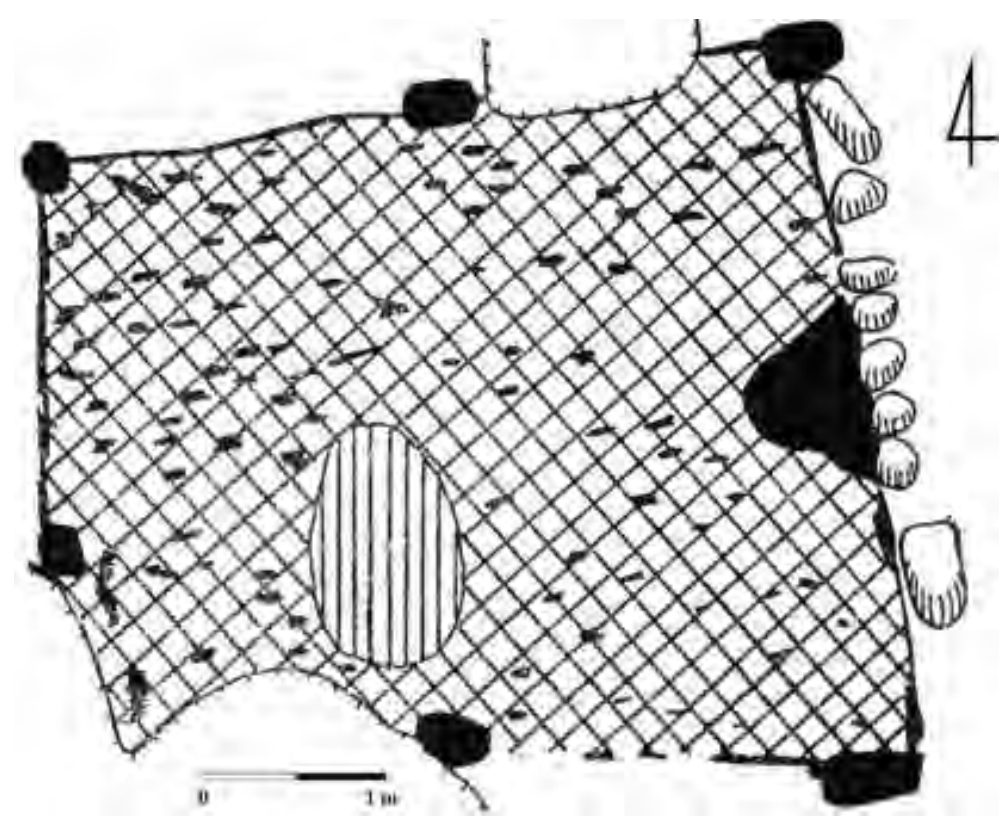

Ryc. 2. Gaj, pow. Koło, woj. wielkopolskie, stan. 1. Rzut poziomy „domu kultowego” (wg: Chmielewski 1952, ryc. 52)

Fig. 2. Gaj, Koło county, Wielkopolskie province, site 1. Layout of a cult house (after Chmielewski 1952, Fig. 52)

Budowlę ze stanowiska w Gaju wzniesiono najprawdopodobniej w konstrukcji sumikowo-łątkowej. Była ona kształtem zbliżona do trapezu o wymiarach boków $\mathrm{N}$ i S $-5 \mathrm{~m}, \mathrm{E}-4,4 \mathrm{~m}, \mathrm{~W}-3 \mathrm{~m}$ (ryc. 2). Podłoga obiektu była wylepiona gliną, tworząc gładkie klepisko, na środku którego znajdowała się jama o wymiarach 
$1,35 \times 0,9 \mathrm{~m} . \mathrm{W}$ jej wypełnisku zarejestrowano szarą glinę i piasek z kawałkami węgli drzewnych i polepy. Na jej dnie znaleziono cztery fragmenty ceramiki KPL. Powyżej klepiska odkryto przepalone, zwęglone dranice lub ich fragmenty, polepę oraz kamienie. Konstrukcja dachu nie zachowała się. Według W. Chmielewskiego (1952, s. 90) mógł on być dwuspadowy, może z dranic, oparty na dwóch słupach i ślemieniu. Wejście do tej budowli znajdowało się prawdopodobnie między dwoma kamieniami czoła grobowca. Obiekt ten zapewne uległ spaleniu już po ukończeniu budowy nasypu grobowca. Niewyjaśniona pozostaje przyczyna jego spalenia (Chmielewski 1952, s. 88-91, ryc. 51-52).

Kolejną budowlę drewnianą odkryto na stanowisku w Obałkach. Wewnątrz grobowca $\mathrm{nr} 2$, tuż przy jego podstawie, zarejestrowano warstwę gliny o grubości $0,15 \mathrm{~m}$, o kształcie kwadratu z lekko zaokrąglonymi bokami, długości 4,8 m. Na jej środku odkryto jamę. Charakter jej wypełniska świadczy o tym, że pozostawała przez dłuższy czas niezasypana. Być może pełniła ona funkcję miejsca, w którym składano jakieś nieokreślone ofiary (?). Do wnętrza budowli wchodziło się od strony wschodniej, gdzie była przerwa między kamieniami obstawy grobowca. Omawiany obiekt prawdopodobnie uległ spaleniu (Chmielewski 1952, s. 83-86, ryc. 47).

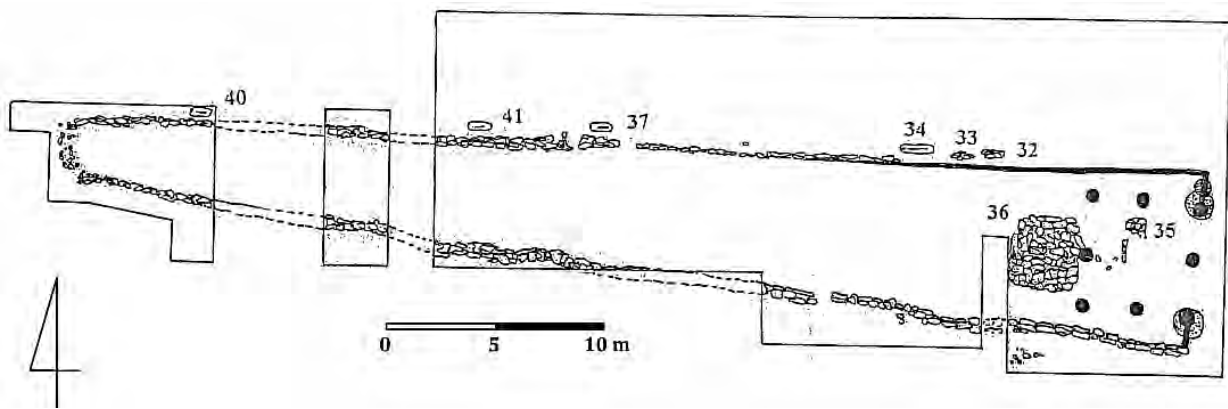

Ryc. 3. Pawłów, pow. Sandomierz, woj. świętokrzyskie, stan. 3. Plan grobowca nr I z „domem kultowym" we wschodniej części obiektu (wg: Bargieł, Florek 2006b, ryc. 2)

Fig. 3. Pawłów, Sandomierz county, Świętokrzyskie province, site 3. Layout of grave No. I with a cult house in an eastern part of a megalith (after Bargieł, Florek 2006b, Fig. 2)

Jeden z większych „domów kultowych” zarejestrowano w Pawłowie. Znajdował się on we wschodniej części grobowca megalitycznego. Wejście umieszczone w czole megalitu umożliwiało kontakt z jego wnętrzem (ryc. 3). Szkielet budowli tworzyło osiem słupów, które ograniczały przestrzeń o wymiarach $8 \times 6 \mathrm{~m}$. Omawiana konstrukcja miała drewniane ściany (ich pozostałością był płytki rowek). Według Barbary Bargieł i Marka Florka (2005, s. 23-25; 2006b, s. 388-389) dach był prawdopodobnie płaski lub niski dwuspadowy, przypuszczalnie pokryty słomą bądź 
trzciną, o czym świadczy duże nagromadzenie szczątków organicznych w tej części budowli. Prawdopodobnie pochodziły one ze zbutwiałego i zawalonego poszycia. Wewnątrz tej konstrukcji znaleziono liczne fragmenty naczyń, drobne wyroby krzemienne oraz węgle drzewne. Za „domem kultowym” znajdował się bruk kamienny nakrywający pochówki (Bargieł, Florek 2006b, s. 393, ryc. 13).

Następny „dom kultowy” odkryto także na stan. 3 w Pawłowie na wschód od grobów 16, 17 i 19. Zarejestrowano tu siedem dołów posłupowych, będących prawdopodobnie pozostałością naziemnego budynku o wymiarach około 4,5 $\mathrm{m} \times 3,8 \mathrm{~m}$ (Florek 2008, s. 116). Niewykluczone, że stanowi on część jednego założenia przestrzennego wraz z ,podkowiastym” rowem i wymienionymi grobami (Bargieł, Florek 2006b, ryc. 2). Dlatego został zaliczony do kategorii „domów typu A”. Podobnie jak w budowli kultowej, znajdującej się w grobowcu megalitycznym na tym samym stanowisku, także w tym miejscu mogły się odbywać jakieś bliżej nieokreślone obrzędy (Bargieł, Florek 2006b, s. 391; Florek 2008, s. 116). Niestety w tekście nie ma informacji o ewentualnym materiale zabytkowym. Brakuje śladów świadczących o pożarze omawianej budowli.

Dwa bardzo dobrze rozpoznane wykopaliskowo „domy kultowe” zostały odkryte na stan. $3 \mathrm{w}$ Zberzynie. Pierwszy z nich zarejestrowano w partii czołowej grobowca nr IV, przy jego podstawie. Pozostałości budowli wystąpiły w postaci intensywnie czarnych smug i plam spalenizny z domieszką węgielków drzewnych. Miała ona kształt czworoboku zbliżony do trapezu. Długość ścian południowej, wschodniej i północnej wynosiła 4,5 m, natomiast ściany zachodniej - $4 \mathrm{~m}$. Ścianki miały ok. 4-5 cm grubości. W narożnikach i w połowie długości ścian zarejestrowano dołki posłupowe o średnicy 0,3-0,4 m. Oś wschód-zachód budowli odchylona była ok. $20^{\circ}$ na południe. Podłogę stanowiło gliniane klepisko, o grubości ok. $0,1 \mathrm{~m}$. Glina w klepisku była ubijana, a następnie wypalana (na powierzchni gliny zalegała warstewka spalenizny o miąższości ok. $0,5 \mathrm{~cm}$, a nad nią kolejny poziom gliny), zarejestrowano na niej również zwęglone kości zwierzęce. Według K. Gorczycy (1981, s. 16-18) ściany „domu” mogły mieć wysokość ok. 1,6 m i prawdopodobnie wykonane były w konstrukcji sumikowo-łątkowej. Autor podaje także, że dach budowli był prawdopodobnie czterospadowy, a jego wysokość w partii szczytowej mogła osiągać nawet $3,5 \mathrm{~m}$. Te ustalenia należy jednak przyjmować z ostrożnością. Kwestią nierozstrzygniętą pozostanie okres użytkowania obiektu, choć K. Gorczyca przypuszcza, że „dom kultowy” ze Zberzyna użytkowano prawdopodobnie ok. 30-40 lat; na tyle szacuje trwałość drewna jesionowego. Po tym okresie nastąpił pożar budowli. Przyczyny i charakter pożaru nie są znane (Gorczyca 1981, s. 16-18).

Drugi obiekt tego typu został odkryty w partii czołowej grobowca $\mathrm{I}^{3}$. Rysował się jako kwadratowe zaciemnienie o wymiarach $4 \times 4 \mathrm{~m}$ (ryc. 4). Według K. Gor-

\footnotetext{
${ }^{3}$ Serdecznie dziękuję mgr. Krzysztofowi Gorczycy z Muzeum Okręgowego w Koninie za udostępnienie mi niepublikowanych wyników badań grobowca I.
} 
czycy „dom kultowy” został wzniesiony najprawdopodobniej w konstrukcji sumikowo-łątkowej. Jego podłoga pokryta była cienką warstwą polepy. Na klepisku zarejestrowano przepalone i rozdrobnione kości zwierzęce oraz dwa skupiska silnie przepalonych kamieni, będące pozostałościami dwóch palenisk. W tej części obiektu znaleziono także największe skupienie fragmentów ceramiki KPL. Szczególne jej zagęszczenie zanotowano również w części wschodniej, gdzie najprawdopodobniej znajdowało się wejście do wnętrza „domu kultowego”. Budowla uległa spaleniu, po czym, jak twierdzi autor opracowania, jej ściany przewróciły się do wewnątrz pod naporem piasku i zostały nim częściowo przykryte (Gorczyca 2007, s. 6-8).

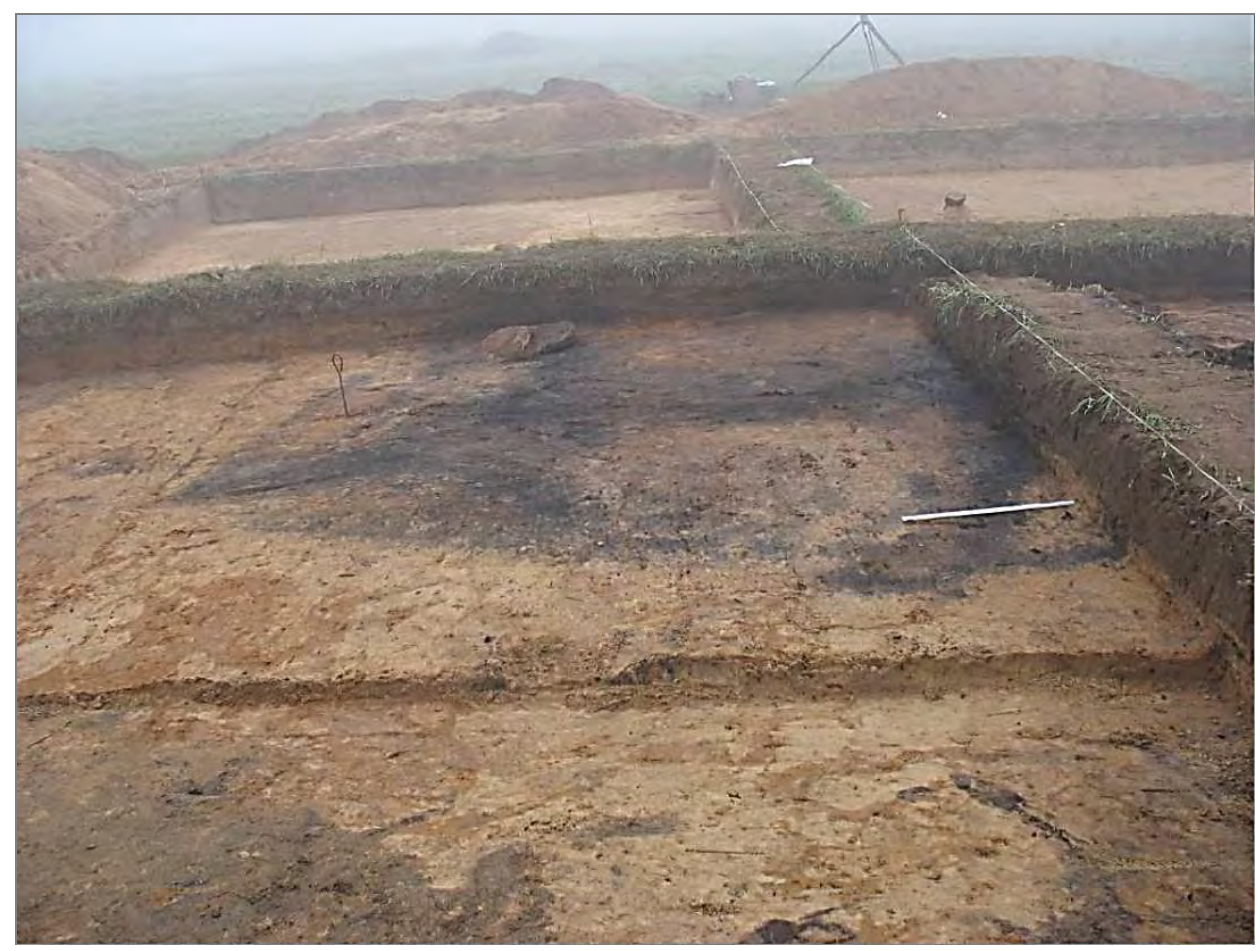

Ryc. 4. Zberzyn, pow. Konin, woj. wielkopolskie, stan. 3. Grobowiec I, wykop C. Widok „,domu kultowego" od zachodu (wg: Gorczyca 2007)

Fig. 4. Zberzyn, Konin county, Wielkopolskie province, site 3. Barrow I, trench C. View of a cult house to E (after Gorczyca, 2007)

Wspólną cechą „domów kultowych typu A” jest lokalizacja w czołowej, zazwyczaj wschodniej - szerszej części grobowca. Konstrukcje tego rodzaju nie są wznoszone nad grobem/grobami ludności KPL. Przeważnie w czole megakonstrukcji znajduje się wejście umożliwiające komunikację z wnętrzem „,domu”. Niewyklu- 
czone przy tym, że z wnętrza „domu kultowego typu A” istniało przejście dalej, $\mathrm{w}$ głąb grobowca. Każda $\mathrm{z}$ omówionych budowli posiada indywidualne cechy konstrukcyjne. Odmienne są także ich rozmiary. Dwóm z przedstawionych budowli towarzyszą paleniska (Broniszowice, Zberzyn). Warstwę polepy odkryto wewnątrz obiektów w Gaju, Obałkach i w obu konstrukcjach w Zberzynie. Natomiast cztery budowle tego typu uległy pożarowi (Gaj, Obałki oraz 2 obiekty w Zberzynie). W dwóch „,domach typu A”, na ich środku, zarejestrowano jamy (Gaj, Obałki).

\section{„DOMY KULTOWE TYPU B”}

Do tej grupy zaklasyfikowano osiem obiektów (tab. 1). Ich cechą wspólną jest usytuowanie wewnątrz megakonstrukcji nad grobem/grobami ludności KPL. Podobnie jak „domy typu A” obiekty tego rodzaju zlokalizowane są w czołowej, wschodniej części grobowca. Poniżej została przedstawiona ich krótka charakterystyka.

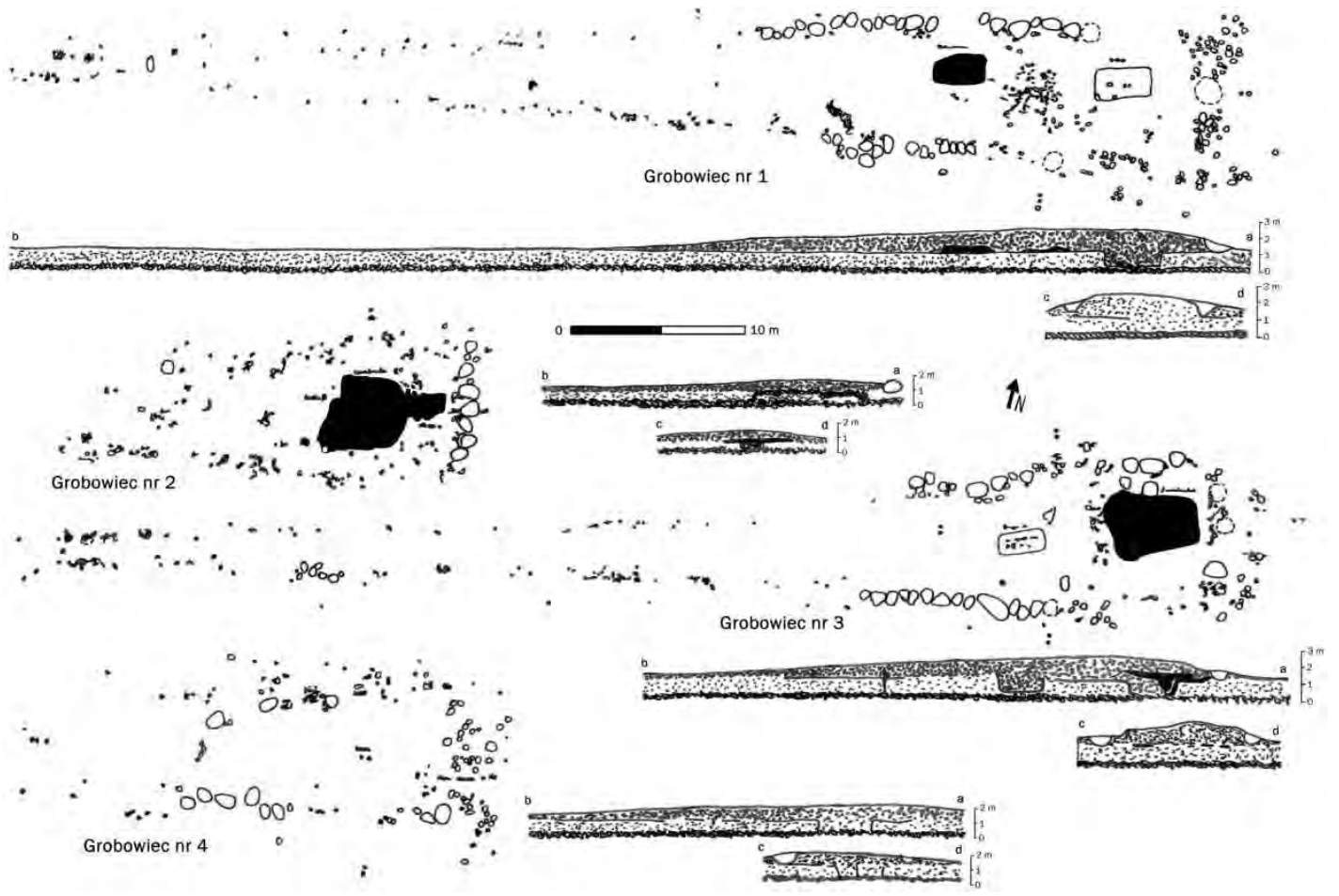

Ryc. 5. Plan grobowców nr 1, 2, 3 i 4 (od góry) z Leśniczówki (wg Jażdżewski 1936a). Ciemnym kolorem zaznaczono „domy kultowe” typu B

Fig. 5. Layout of graves No. 1, 2, 3 and 4 (from above) from Leśniczówka (after Jażdżewski 1936a). Cult houses of type B marked with a dark colour 
Dwie konstrukcje tego typu zostały odkryte na stanowisku 1 w Leśniczówce. Pierwszą z nich zarejestrowano $6 \mathrm{~m}$ od podstawy grobowca $\mathrm{nr} 2$ (ryc. 5). Rysowała się ona jako ciemnobrunatna warstwa, interpretowana przez K. Jażdżewskiego jako warstwa ogniskowa. Miała ona kształt w przybliżeniu trapezowaty o wymiarach 4,5 $\times 4,5 \mathrm{~m}$ i miąższości $0,25 \mathrm{~m}$. W warstwie tej zarejestrowano dużą liczbę fragmentów naczyń, głównie pucharów i amfor, kółko miedziane, wyroby krzemienne, połupane kości zwierzęce. Pod warstwą ogniskową odkryto grób (nr „,b”). Jama grobu miała kształt prostokątny o wymiarach $2,8 \times 1,3 \mathrm{~m}$, o osi podłużnej zgodnej z długością grobowca. Była ona zagłębiona do ok. $0,3 \mathrm{~m}$ poniżej poziomu dawnej próchnicy i nakryta brukiem kamiennym. Kości szkieletu nie zachowały się, również nie zarejestrowano wyposażenia (Jażdżewski 1936a, s. 172-182; Chmielewski 1952, s. 73- 80).

Rozmiary i miejsce usytuowania warstwy ogniskowej w czole grobowca, tuż za jego podstawą, pozwalają identyfikować ten obiekt z „domem kultowym”. Bogaty materiał zabytkowy, a także obecność jamy grobowej pod tą konstrukcją dodatkowo potwierdza tę hipotezę. Omawiana budowla zapewne uległa spaleniu. Brakuje danych na temat konstrukcji ścian i dachu, ale prawdopodobnie była to budowla o konstrukcji naziemnej lub niewiele zagłębiona w podłoże. Opisany obiekt wykazuje liczne podobieństwa do budowli ze Zberzyna, Obałek czy Gaju, lecz obecność jamy grobowej zarejestrowanej pod nim nakazuje go zaliczyć do „domów typu B”.

Drugą ze wzmiankowanych konstrukcji w Leśniczówce zarejestrowano w grobowcu nr 3 (ryc. 5). W odległości $1 \mathrm{~m}$ od podstawy, bliżej ściany północnej odkryto intensywnie czarną warstwę ziemi z licznymi w niej węgielkami drzewnymi, którą K. Jażdżewski zinterpretował jako warstwę ogniskowa. Miała ona kształt trapezowaty o wymiarach $5,0 \times 4,2 \times 3,0 \mathrm{~m}$. Jej miąższość wahała się od 0,15 do $0,2 \mathrm{~m}$. $\mathrm{W}$ jednym miejscu warstwa ta przechodziła $\mathrm{w}$ jamę o głębokości $0,9 \mathrm{~m}$, wkopaną w jamę grobu „c" - kształtu prostokątnego, o wymiarach 2,8 $\times 1,5 \mathrm{~m}$. Na jego dnie znaleziono szkielet, z którego zachowały się tylko kości długie. W północno-zachodnim narożniku warstwy ogniskowej odkryto szkielet dziecka ułożony na wznak z nogami wyprostowanymi. K. Jażdżewski (1936a, s. 172-182) uważa, iż była to jakaś ofiara. Natomiast zdaniem W. Chmielewskiego (1952, s. 79) szkielet dziecka nie zdradza żadnych cech nadzwyczajności i należy go traktować jako jeden z pochówków złożonych w tym grobowcu. Dziecko zostało pochowane po wygaśnięciu ogniska. Obaj autorzy zgadzają się, że grób dziecka na pewno nie został wkopany w nasyp grobowca.

Wydaje się jednak słuszne sformułowanie hipotezy alternatywnej, w myśl której nie mamy tu do czynienia z ogniskiem, ale z „domem kultowym typu B”. Świadczą o tym kształt, rozmiar i usytuowanie obiektu w czole grobowca, a także jama odkryta we wnętrzu hipotetycznego ,domu”. Analogiczne jamy zostały odkryte w budowlach drewnianych na stanowiskach w Gaju i Obałkach. Konstrukcję tę zbudowano nad zasypaną wcześniej jamą ,grobu c”. Brakuje danych na temat sposobu budowy ścian i dachu. Przypuszczalnie było to założenie o konstrukcji naziemnej lub niewie- 
le zagłębione w podłoże. Po destrukcji „domu kultowego” musiał odbyć się pochówek dziecka. Następnie prawdopodobnie dokończono budowę nasypu nad wschodnią częścią grobowca.

Kolejna konstrukcja drewniana została ujawniona na stanowisku 6 w Łącku. $\mathrm{W}$ grobowcu 2 odkryto skupiska polepy tworzące okręg o średnicy ok. $7 \mathrm{~m}$. W jego granicach zarejestrowano 9 dołków posłupowych wypełnionych polepą. Ponadto zidentyfikowano pięć kolejnych dołków posłupowych, ale ich przynależność do opisywanego założenia nie jest pewna (Rzepecki 2004, s. 127). Dołki tworzyły owalną konstrukcję słupową o wymiarach $6,5 \times 8,0 \mathrm{~m}$, która została zbudowana nad jamą grobową. Wejście do obiektu znajdowało się najprawdopodobniej od strony północno-wschodniej. Może na to wskazywać układ dołków, które w tym miejscu wyznaczają niewielki korytarz prowadzący do wnętrza budowli. Jego wymiary wynoszą: szerokość - $1,0 \mathrm{~m}$, a długość - $0,8 \mathrm{~m}$. Słupy tworzące tę konstrukcję zostały wkopane na głębokość $0,1 \mathrm{~m} \mathrm{w}$ warstwę żwiru utwardzonego gliną. Wszystkie dołki były okrągłe, o średnicy około $0,3 \mathrm{~m}$. W skład ich wypełniska wchodziła glina ze żwirem i ślady węgli drzewnych. Prawdopodobnie budowla została spalona (Domańska 1995, s. 8-10; 2006, s. 289-298; Rzepecki 2004, s. 24-128).

W grobowcu $\mathrm{nr} 1 \mathrm{w}$ Malicach Kościelnych także odkryto pozostałości po tzw. domu kultowym. Czytelne były one w postaci czterech dołów posłupowych. Trzy z nich miały głębokość $0,45-0,5 \mathrm{~m}$, a ich średnice wynosiły od $0,35 \mathrm{~m}$ do $0,5 \mathrm{~m}$. Natomiast czwarty słup, najbardziej wysunięty w kierunku wschodnim, miał średnicę ponad $0,8 \mathrm{~m}$, a był wkopany na głębokość ok. $1 \mathrm{~m}$. Wejście do budowli umieszczone było we wschodniej ścianie grobowca (Bargieł, Florek, Libera 1999, ryc. 2; Bargieł, Florek 2006a, s. 365-366, 368). Wewnątrz omawianego pomieszczenia znajdowały się trzy jamy grobowe (nr 14, 19 i 31). Były one zorientowane prostopadle do osi grobowca, po linii N-S, przy czym zbudowano je tak, aby nakrywające je bruki kamienne nie wystawały ponad powierzchnię użytkową „domu kultowego”. Pochówki odkryte $\mathrm{w}$ obrębie budowli w podstawie grobowca zostały tam umieszczone już w trakcie jej użytkowania (Florek 2008, s. 114-115).

„Dom kultowy typu B” odkryto również w Pawłowie, w grobowcu II - w tzw. budowli stupowej (ryc. 6). Cała „megakonstrukcja” ma długość prawie $30 \mathrm{~m}$. Jej ściany tworzyło 37 słupów drewnianych umieszczonych w dwóch rzędach w przybliżeniu na osi E-W. Średnice dołów posłupowych wynosiły ok. 0,4-0,5 m. Odległość między rzędami słupów wynosiła od $6 \mathrm{~m}$ w partii centralnej budowli do $3 \mathrm{~m}$ na jej końcach. Natomiast kolejne słupy w rzędach oddalone były od siebie przeciętnie o ok. 1,5 m. Słupy stanowiły prawdopodobnie element nośny dachu i ścian. Te mogły być wykonane z plecionki, z belek lub dranic i prawdopodobnie w konstrukcji sumikowo-łątkowej. Mniej więcej w 2/3 długości budowli, od strony W, znajdowały się dodatkowe wewnętrzne słupy, dzielące ją na dwie części i jednocześnie wspierające dwu- lub czterospadowy dach. Jej plan badacze rekonstruują w formie dwóch wysokich, stykających się podstawami trapezów, bądź płaskiej soczewki z 
wewnętrzną, poprzeczną ścianą w najszerszym miejscu. Wejście do budowli znajdowało się od strony wschodniej, w węższej ścianie. Wewnątrz badanego obiektu odkryto siedem grobów ludności KPL (Bargieł, Florek 2006b, s. 385-387; Florek 2008, s. 115-116).

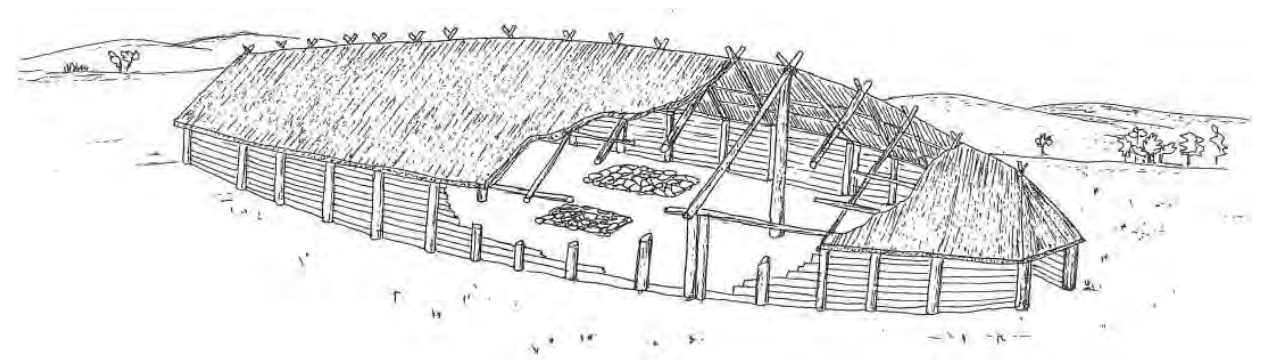

Ryc. 6. Pawłów, pow. Sandomierz, woj. świętokrzyskie, stan. 3. Rekonstrukcja budowli słupowej (sanktuarium) ludności kultury pucharów lejkowatych (wg: Bargieł, Florek 2002, s. 30)

Fig. 6. Pawłów, Sandomierz county, Świętokrzyskie province, site 3. Reconstruction of a beam construction (sanctuary) of TRB (after Bargiel, Florek 2002, p. 30)

Według M. Florka (2008, s. 116) budowlę słupową można traktować jako pewną modyfikację formy grobowców trapezowatych, różniącą się przede wszystkim brakiem obstaw kamiennych, lecz zawierającą te same rozwiązania przestrzenne, funkcjonalne i ideowe. Badacz twierdzi także (Florek 2008, s. 116), że: „[...] jej część wschodnia (do słupów dzielących ją na dwie części) wydaje się być odpowiednikiem pomieszczeń $z$ dachami wspartymi na słupach zajmującymi wschodnie partie megalitycznych grobowców trapezowatych, pełniących funkcje kultowe i obrzędowe, ale również mogących być miejscem pochówków [...]" .

W obrębie omawianego „domu kultowego" zarejestrowano trzy groby. Były one usytuowane między wejściem do megakonstrukcji a wewnętrznymi słupami, dzielącymi ją na dwie części. Umieszczono je w ten sposób, żeby nie wystawały ponad powierzchnię użytkową wnętrza tej części budowli (Florek 2008, s. 115-116). Na tej podstawie omawianą konstrukcję można zaliczyć do „domów kultowych typu B”.

Na stanowisku 1 w Sarnowie zarejestrowano obecność dwóch konstrukcji drewnianych. Obiekt będący najprawdopodobniej pozostałością po „domu typu B” odkryto w megalicie nr 8. Świadectwem istnienia tej konstrukcji jest przepalona i pokruszona polepa, układająca się prawie jednolitą warstwą między grobem centralnym a ścianą czoła grobowca oraz luźnymi skupiskami wokół grobu centralnego. Może to sugerować, iż pierwotnie „dom kultowy” został wzniesiony nad tym grobem. Dodatkowo zarejestrowano kilka dość głębokich dołków układających się podwójnym rzędem równolegle do osi podłużnej grobowca (Gabałówna 1968, 
s. 136). Na polepie odciśnięte zostały ślady „gałęzi i prętów”, co może sugerować obecność konstrukcji drewnianej oblepionej gliną. Prawdopodobnie konstrukcja została spalona.

Powyższe dane oraz analogia do budowli w Łącku, gdzie także zarejestrowano warstwę polepy wokół grobu, umożliwiają zakwalifikowanie omawianego obiektu do kategorii „domów kultowych typu B”. W literaturze przedmiotu zakres rozbieżności w interpretacji dołków wraz z towarzyszącym im skupiskiem polepy jest jednak duży - korytarz prowadzący do grobu, budowla kultowa, dom związany z osadnictwem ludności KPL (por. Niesiołowska-Śreniowska 1982, s. 111-112; Wiklak 1982, s. 61-63).

Budowla drewniana $\mathrm{z}$ grobowca $9 \mathrm{w}$ Sarnowie została wzniesiona w konstrukcji zrębowej. Usytuowana została nie przy podstawie, ale w głębi megalitu, gdzie częściowo przykrywała jamę grobową. Budynek kształtem zbliżony był do prostokąta, jego wymiary wynosiły $3,0 \times 2,4 \mathrm{~m}$. Zbudowany był dokładnie na osi N-S. Wewnątrz niego, w narożniku północno-wschodnim, znajdowało się mniejsze pomieszczenie o wymiarach 2,0 × 1,6 m. Od strony zachodniej całość założenia uzupełniała „przybudówka” o wydłużonym kształcie i zaokrąglonych narożnikach, zorientowana ukośnie w stosunku do ściany głównego budynku, natomiast prostopadle do osi grobowca (Wiklak 1975, ryc. 3). Jedna ze ścian ,przybudówki” przecięta była niewielkim korytarzykiem od strony wschodniej przy ścianie budynku głównego. Wewnątrz budowli nie zarejestrowano żadnych zabytków (Wiklak 1975, s. 49). Nie stwierdzono również śladów pożaru.

„Dom kultowy typu B” zarejestrowano także prawdopodobnie podczas badań w Wietrzychowicach. W odległości ok. 1,2 m od czoła grobowca $\mathrm{nr} 5$ znajdowały się dwa dołki posłupowe o średnicy $0,4 \mathrm{~m}$, oddalone od siebie o $1 \mathrm{~m}$. Dwa następne zarejestrowano po północnej stronie grobu centralnego. Wypełniska dołków stanowiła szara ziemia zmieszana z piaskiem; zabytków nie stwierdzono. Luka w obstawie czoła grobowca (pośrodku osi podłużnej) pozwala przypuszczać, że w tym przypadku możliwy był dostęp do tej budowli z zewnątrz. Według Ireny Jadczykowej mogą to być pozostałości korytarza łączącego wejście w czole grobowca $\mathrm{z}$ jamą grobową (1970, s. 134-135, 1972, s. 101). Niestety na opublikowanym planie (Jadczykowa 1970, ryc. 5) nie zostały przedstawione pozostałości opisywanej konstrukcji.

Można przyjąć hipotezę alternatywną, że są to pozostałości po budowli - „domu kultowym” stawianym często przy podstawie megalitu. W tym przypadku omawiana konstrukcja mogła zostać zbudowana nad grobem centralnym. Pierwotnie liczba dołków posłupowych wokół jamy grobowej mogła być większa. Pozostałości dołków prawdopodobnie uległy wcześniej destrukcji, dlatego nie udało się ich zarejestrować w trakcie badań archeologicznych.

Wszystkie omówione konstrukcje pierwotnie zostały wzniesione nad grobem/ grobami ludności KPL. Na wzór „duński” pełniły funkcję „domów zmarłych” (Madsen 1979, s. 307-315) oraz były miejscem, w którym bliscy zmarłego podczas czyn- 
ności obrzędowo-sakralnych mogli się z nim pożegnać. Każdy z tych obiektów posiada indywidualne cechy konstrukcyjne. Odmienne są również rozmiary. W przypadku czterech z nich stwierdzono ślady pożaru (dwa obiekty w Leśniczówce, Łącko i Sarnowo).

\section{HIPOTETYCZNE „DOMY KULTOWE”}

Do tej kategorii zaliczono pięć konstrukcji (tab. 1), które prawdopodobnie są pozostałościami „domów kultowych”.

Ślady domniemanego „domu kultowego” odkryto najprawdopodobniej w grobowcu V/96 w Karmanowicach, gdzie 11 dołków posłupowych tworzyło w miarę regularny układ. Ich średnica wynosi od ok. $0,3 \mathrm{~m}$ do $0,55 \mathrm{~m}$, a głębokość od 0,25 do $0,33 \mathrm{~m}$. W ich wypełniskach natrafiono na fragmenty ceramiki, przepalone ułamki kości i okruchy polepy (Nogaj-Chachaj 1997, s. 16-23; 1998, s. 30-35).

Trudno rozstrzygnąć, czy odkryte dołki są pozostałością konstrukcji dobudowanej przy wejściu do grobowca, czy są reliktem wcześniejszego lub późniejszego osadnictwa na tym stanowisku. Nie można także wykluczyć, że odkryte dołki są śladami po „domu kultowym” zbudowanym nad jamą VI/97.

Piętnaście metrów od podstawy grobowca nr $1 \mathrm{w}$ Leśniczówce, bliżej ściany północnej, w nasypie zarejestrowano „ciemnobrunatno zabarwioną warstwę” (ryc. 5). Zawierała ona liczny materiał zabytkowy w postaci węgli drzewnych, fragmentów naczyń i kości zwierzęcych. Warstwa ta zalegała na próchnicy pierwotnej, tworząc w przybliżeniu prostokąt o wymiarach 2,3 $\times 1,7 \mathrm{~m}$ i orientacji północny wschód-wschód - południowy zachód-zachód. Jej miąższość wynosiła $5 \mathrm{~cm}$. Od jej strony południowej odkryto trzy dołki posłupowe o średnicy $0,3 \mathrm{~m}$ i głębokości 0,1 m, być może z nią powiązane (Chmielewski 1952, s. 74; Jażdżewski 1936a, s. 172-182). Mogą to być pozostałości po „domu kultowym” wzniesionym na słupach. Brakuje danych na temat ewentualnej konstrukcji ścian i dachu.

W części wschodniej grobowca II w Malicach Kościelnych mogła znajdować się podobna konstrukcja do tej odkrytej w grobowcu I, lecz ze względu na silne zniszczenie nie można nic pewnego powiedzieć na temat jej formy (Bargiel, Florek 2006a, s. 372; Bargieł, Florek, Libera 1999, ryc. 2). To podobieństwo oraz obecność grobów ludności KPL w czole grobowca zbliżają ten obiekt do „domów kultowych typu B”.

Podczas badań grobowca $3 \mathrm{w}$ Wietrzychowicach, w odległości $5,7 \mathrm{~m}$ od podstawy megalitu odkryto „pas ciemnej, tłustej ziemi”. Jego szerokość wynosiła 1,7 m. W obrębie tego obiektu stwierdzono ułamki naczyń, krzemienie, połupane kości zwierzęce, fragment potłuczonej czaszki ludzkiej oraz liczne węgle drzewne. Grubość tej warstwy wahała się od 0,15 do $0,35 \mathrm{~m}$. Pod nią odkryto bruki kamienne nakrywające dwa groby. Według K. Jażdżewskiego (1936b, s. 121-129) omawiana wyżej warstwa stanowi ślady stypy pogrzebowej i rytualnego ludożerstwa. 


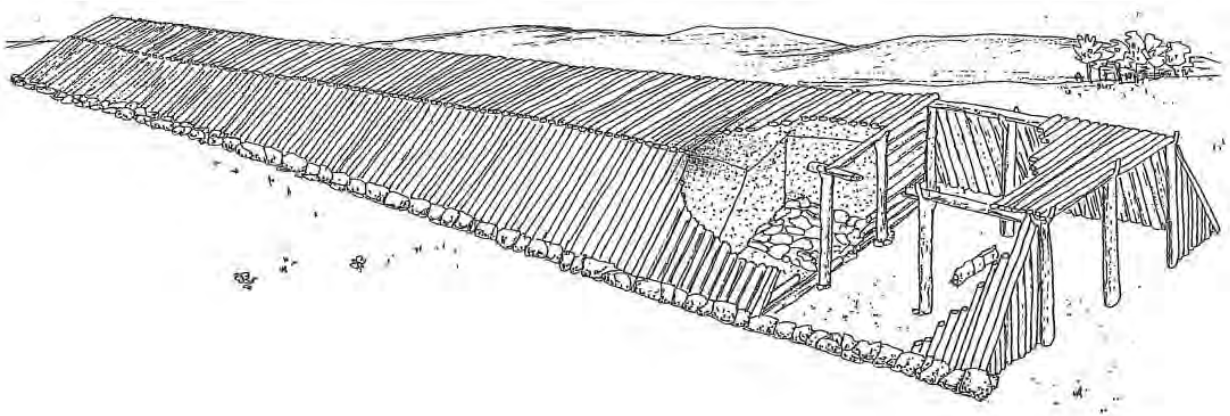

Ryc. 7. Pawłów, pow. Sandomierz, woj. świętokrzyskie, stan. 3. Rekonstrukcja grobowca megalitycznego ludności kultury pucharów lejkowatych z zaznaczonym „domem kultowym” (wg: Bargieł, Florek 2002, s. 30)

Fig. 7. Pawłów, Sandomierz county, Świętokrzyskie province, site 3. Reconstruction of a megalithic grave of TRB (after Bargieł, Florek 2002, p. 30)

Na podstawie powyższego opisu można sądzić, że jest to raczej pozostałość po jakiejś bliżej nieokreślonej konstrukcji drewnianej należącej, z racji swego usytuowania, do „domów typu B”. Przerwa między kamieniami obstawy w podstawie grobowca może sugerować, iż możliwy był do niej dostęp z zewnątrz. Na temat konstrukcji ścian i dachu brakuje danych. Zapewne odbywały się tutaj stypy bądź bliżej nieokreślone obrzędy (Chmielewski 1952, s. 93). Fragment czaszki ludzkiej mógł dostać się przypadkowo na powierzchnię, ponieważ prawdopodobnie budowla została postawiona niedługo po złożeniu zmarłych do grobu (choć kanibalizmu wykluczyć nie można).

W czole grobowca w Zberzynku zarejestrowano warstwe ogniskowa. Tworzyła ją ,intensywnie czarna, thusta ziemia $\mathrm{z}$ dużą ilością węgielków drzewnych oraz drobnych polnych kamieni występujących w nieregularnym układzie" (Tetzlaff 1961, s. 40). W rzucie poziomym miała ona zarys w przybliżeniu prostokątny o wymiarach ok. $3 \times 4 \mathrm{~m}$. Jej miąższość wynosiła maksymalnie do $0,3 \mathrm{~m}$. Pierwotnie interpretowana była jako pozostałość wielokrotnie rozpalanych w tym miejscu ognisk, przy których odprawiano uczty obrzędowe. Warstwa ta zawierała połupane kości zwierzęce i fragmenty naczyń (Tetzlaff 1961, s. 40-42).

Uzasadnione wydaje się jednak sformułowanie hipotezy alternatywnej, w myśl której są to pozostałości „domu kultowego” stawianego często w czole grobowca. Mogła być to konstrukcja naziemna, która najprawdopodobniej została spalona.

Oprócz przedstawionych powyżej konstrukcji, obecność hipotetycznego „domu kultowego" sygnalizowana jest w literaturze także na stanowiskach w Faliszewie i Iłowie (Chmielewski 1952, s. 45-46; Kozłowski 1921, s. 11-13). Obiekty te nie mogą jednak być zaliczone do tej kategorii. Konstrukcja z Iłowa jest prawdopodobnie kamienną wersją drewnianego „domu” zbliżonego do alei kamiennych ze Świer- 
czynka (Chmielewski 1952, s. 45-46). Z kolei obecność konstrukcji drewnianej w Faliszewie sygnalizowana jest przez R. Zych (2002, por. katalog; 2006, s. 123), lecz w literaturze (Chmielewski 1952, s. 46; Midgley 1985, s. 225), na którą powołuje się autorka, na ten temat nie ma danych. Powyższą informację należy więc traktować jako pomyłkę.

W tym miejscu należałoby się również zastanowić nad obecnością „,domów kultowych” w grobowcach typu „Niedźwiedź” (Rzepecki 2011, s. 13). Grobowce tego typu zostały odkryte m.in. w Niedźwiedziu, Lublinie-Sławinku, Słonowicach i Zagajach Stradowskich (Burchard 1973, 1998, 2006; Jastrzębski, Ślusarska 1982; Tunia 1996, 2003a, 2003b, 2006). Mimo że grobowce na wyżej wymienionych stanowiskach zostały zbudowane $\mathrm{z}$ drewna, to nie ma żadnych przesłanek, aby dopatrywać się w ich części wschodniej „domów kultowych”. W przypadku tzw. megaksylonów z Niedźwiedzia, Lublina-Sławinka i Zagai Stradowskich ich części czołowe (wschodnie) zostały zniszczone (Burchard 1973, s. 42, ryc. 3D; 1998, s. 152, ryc. 2; Jastrzębski, Ślusarska 1982, s. 193, ryc. 3). Miało to miejsce w pradziejach - późniejsze osadnictwo na stanowisku (Zagaje Stradowskie), bądź współcześnie - działania wojenne i budowa drogi (Niedźwiedź, Lublin-Sławinek). Nie ma żadnych czytelnych śladów archeologicznych, aby w podstawach tych obiektów dopatrywać się obecności „domów kultowych”, choć jednoznacznie ich braku nie można wykluczyć. Od kilku lat na stanowisku w Lublinie-Sławinku trwają ratownicze prace wykopaliskowe. Odkryto kolejne grobowce o podobnej konstrukcji do omawianej powyżej (informacje ustne mgr Marty Polańskiej z Muzeum Lubelskiego w Lublinie, za które serdecznie dziękuję).

Podobnie zagadnienie „domów kultowych” można rozpatrywać w kontekście grobowców typu „Niedźwiedź” ze Słonowic. Wejście do wszystkich odkrytych budowli znajdowało się w ścianie wschodniej. Był to rozstęp w „palisadzie”, często posiadający pośrodku słup. Pochówki odkryto kilka metrów od wejścia (Tunia 2006, s. 337, ryc. 2). Lokalizacja słupa w podstawie, pośrodku luki, oraz usytuowanie grobu w niewielkiej odległości od wejścia mogłyby sugerować obecność „domu kultowego". W odniesieniu do tych grobowców nie można mówić o jakiejkolwiek konstrukcji drewnianej w ich czołach. Brakuje słupów oddzielających ją od pozostałej części grobowców typu „Niedźwiedź” (Tunia 2003a, 2003b, 2006, ryc. 2). Nie można również wykluczyć sytuacji, w której cała przestrzeń wewnątrz „słonowickiego" grobowca była dostępna poprzez wejście w jego czole.

\section{DATOWANIE „DOMÓW KULTOWYCH”}

Dotychczas daty ${ }^{14} \mathrm{C}$ uzyskano jedynie dla trzech obiektów zarejestrowanych w grobowcach megalitycznych na stanowiskach w Łącku i Zberzynie (tab. 1). W czasie eksploracji „domu” w Łącku natrafiono na fragment łyżki glinianej pokry- 


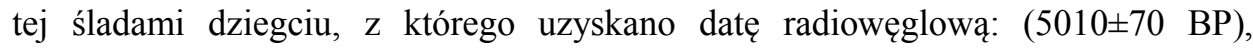
$3820 \pm 90$ BC. Należy ją łączyć z okresem budowy grobowca (Domańska 1995, s. 10; 2006, s. 290; Rzepecki 2004, s. 92).

Stosunkowo najlepiej pod względem datowania bezwzględnego prezentuje się stanowisko 3 w Zberzynie. Uzyskano dwie daty dla dwóch „domów” odkrytych $\mathrm{w}$ grobowcach I i IV. Budowla $\mathrm{z}$ grobowca IV została wydatowana na III (klasycznowiórecką) fazę KPL, co znalazło potwierdzenie w uzyskanej dacie ${ }^{14} \mathrm{C}$ : (4720 \pm 110 BP), $3495 \pm 119$ BC (Gorczyca 1981, s. 15). Natomiast datowanie grobowca I na podstawie analizy ceramiki wskazuje na późny odcinek podfazy IIIB i podfazę IIIC KPL. Analiza metodą ${ }^{14} \mathrm{C}$ węgli drzewnych z „domu kultowego” wewnątrz grobowca przyniosła wynik (4620 \pm 40 BP), $3429 \pm 61$ BC (Wierzbicki 2008, s. 41).

Zbliżone datowanie uzyskano dla innych „domów kultowych”. Na podstawie zarejestrowanego wyposażenia $\mathrm{w}$ jednym $\mathrm{z}$ grobów, odkrytych wewnątrz grobowca z Broniszowic, został on wydatowany na II, klasyczną fazę południowo-wschodniej grupy KPL, tj. na ok. 3640-3480 BC (Bąbel 2006, s. 274). Taką chronologię ma więc „dom kultowy” z broniszowickiego grobowca. Podobne datowanie ma obiekt zarejestrowany w jednym z grobowców w Malicach Kościelnych (Bargieł, Florek, Libera 1998, s. 48).

\section{TECHNIKI BUDOWY „DOMÓW KULTOWYCH”}

Omawiane powyżej budowle wznoszono ówcześnie znanymi technikami konstrukcyjnymi (ryc. 6, 7, 8). Stosowano konstrukcję sumikowo-łątkową i zrębową. Budowanie tzw. domów kultowych nie zawsze wymagało zastosowania tak wyszukanych (jak na ówczesne czasy) technik. Według J.T. Bąbla (2006, s. 282-283) podobny efekt można było uzyskać prostszymi i znacznie mniej pracochłonnymi metodami. Dobrym przykładem zastosowania innych wariantów konstrukcyjnych jest obiekt z Broniszowic (ryc. 8). Proces jego budowy J.T. Bąbel (2006, s. 282-283) przedstawia następująco (por. ryc. 8):

[...] konstrukcję tę rozpoczęto budować od ściany południowej. Wbito (wkopano) w miarę jednakowej długości sześć pali ograniczających ścianę ze wszystkich stron (słupy E, F, H, L. J, M). Słupy F i L ograniczały ścianę od strony wewnętrznej „komory”: słupy H i J od jej strony zewnętrznej. Następnie między nie [słupy - przyp. red.] wsuwano od góry, lub od czasowo otwartego jednego węższego boku (w miejscu słupa M lub E), kolejne równo przycięte drągi i belki drewniane. Gdy osiągnięto zamierzoną wysokość ściany (ok. 2 m), przystąpiono do konstruowania ściany przeciwległej. Wbito (wkopano) 3 słupy (A-C), które ograniczały ścianę od strony wewnętrznej „komory”. Tu już nie były potrzebne słupy blokujące ścianę od strony zewnętrznej, gdyż blokadę stanowiła jednocześnie usypywana i ubijana warstwa ziemi. Długość poziomych belek wy- 
nosiła około $4 \mathrm{~m}$ i musiały one być wszystkie równo przycięte na ten sam wymiar. Z jednej strony ściany wystawały nieco i w miarę równo poza słup $\mathrm{C}, \mathrm{z}$ drugiej zaś musiały sięgać minimum $1 \mathrm{~m}$ poza słup A. Ścianę zachodnią, węższą od obu poprzednich (około $2 \mathrm{~m}$ ), konstruowano układając podłużne belki o długości minimum 2,5 m tak, aby od strony wschodniej blokowały je słup M i poziome belki ściany zachodniej. Dowodem na to, iż w miejscu tym nie zastosowano techniki sumikowo-łątkowej, jest brak w tym miejscu śladów narożnego słupa. Nie wykluczam, iż w miejscu tym wybudowano narożnik komory, tzw. „węgłówką”, ale można było się i bez niej obejść.

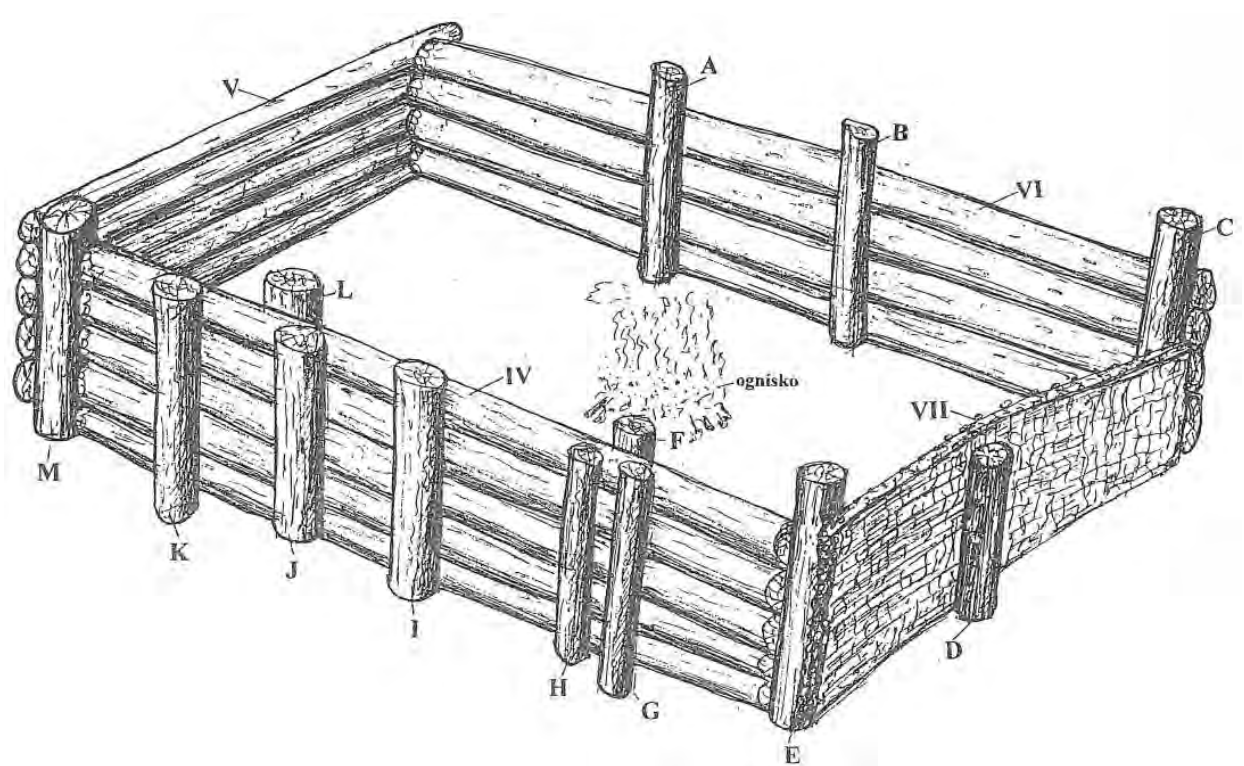

Ryc. 8. Broniszowice, pow. Ostrowiec Świętokrzyski, stan. V-A. Widok aksonometryczny zrekonstruowanego „domu kultowego" grobowca. A-M - słupy pionowe; I, II, III - belki rozporowe; IV, V, VI - ściany boczne; VII - wejście i plecionkowe drzwi (wg: Bąbel 2006, ryc. 11)

Fig. 8. Broniszowice, Ostrowiec Świętokrzyski county, site V-A. Axonometric view of a reconstructed cult house in a barrow. A-M - vertical posts; I, II, III - spreader beams; IV, V, VI - sidewalls; VII - entrance and plaited door (after Bąbel 2006, Fig. 11)

Niestety w trakcie badań, poza kilkoma wyjątkami (taka sytuacja zaistniała m.in. w Gaju czy Zberzynie - Chmielewski 1952, s. 88-91, ryc. 51-52; Gorczyca 1981, s. 16-18), nie udało się odkryć zachowanych ścian tych budowli. Ich rekonstrukcja w wielu przypadkach z powodu braku danych archeologicznych opiera się wyłącznie na przypuszczeniach badaczy (ryc. 6,7,8). Na podstawie źródeł etnograficznych wiążą oni konkretną konstrukcję z określonym rodzajem dachu nakrywającego (Bąbel 2006, s. 275-279; Chmielewski 1952, s. 85-92; Gorczyca 1981, s. 16-18). W kilku przypadkach podłogi tych budowli zostały wyłożone gliną (Gaj, 
Łącko, Obałki, Zberzyn). Odrębną kwestią, o której będzie jeszcze mowa, są jamy wewnątrz „domów kultowych” (odkryto je w Gaju, Leśniczówce i Obałkach), a także pożary tych budowli (np. Gaj, Obałki, Zberzyn).

Różnice konstrukcyjne, które są widoczne w tych budowlach, można m.in. tłumaczyć różnym poziomem wiedzy i umiejętności budowniczych. W podobnym tonie wypowiada się K. Gorczyca, który ponadto uważa, że forma „domu kultowego” mogła mieć znaczenie rytualne (Gorczyca 1981, s. 18). Nie należy jednak odrzucać kwestii tradycji i idei przekazywanej z ojca na syna, a dotyczącej technik budowy. Warto również w tym miejscu wspomnieć o trwałości tego typu obiektów. J.T. Bąbel (2006, s. 278) stwierdza, że „konstrukcja palowa domu, a także grobowca ma tę wadę, iż ta część słupów, która była wkopana (lub wbita) w ziemię, szybko gnije i próchnieje, osłabiając całą budowlę i powodując jej zawalenie. Można temu na jakiś okres zapobiec, smarując końce pali smołą lub opalając je w ognisku. Niemniej jednak czas istnienia takiego budynku liczy się w przybliżeniu na okres życia jednej generacji ludzkiej”. Podobnie szacuje K. Gorczyca (1981, s. 18) trwałość tego typu konstrukcji. Twierdzi on, że okres użytkowania budowli nie mógł być dłuższy niż 30-40 lat. Natomiast w przypadku zastosowania pali dębowych w ,domu kultowym" czas jego trwania szacuje się na około 100 lat (Gorczyca 1981, s. 18).

\section{POŻARY „DOMÓW KULTOWYCH”}

Budowle, które uległy pożarowi, zarejestrowano w dziewięciu grobowcach megalitycznych (tab. 2). Warto zaznaczyć, że takie przypadki zostały potwierdzone tylko na obszarze grupy wschodniej KPL (Chmielewski 1952, s. 72-92; Gorczyca 1981, s. 16-18, 2007, s. 6-8; Socha 2011, s. 60-61; Wiklak 1982, s. 61-63). W grupie południowo-wschodniej KPL wśród dotychczas rozpoznanych budowli nie zarejestrowano śladów pożaru (np. Bargieł, Florek 2006a, 2006b; Bąbel 2006; Florek 2008). Trudno dziś stwierdzić, czy pożar „domu kultowego” miał jakieś znaczenie rytualne, czy był działaniem praktycznym, czy może katastrofą.

Badacze przypuszczają, że pożary „domów kultowych” następowały z reguły po zbudowaniu grobowca megalitycznego i usypaniu nad nimi nasypu ziemnego. We wszystkich omawianych budowlach stwierdzono obecność spalenizny i węgli drzewnych. W Gaju nad klepiskiem odkryto przepalone, zwęglone dranice lub ich fragmenty, polepę oraz kamienie (Chmielewski 1952, s. 90). Natomiast w Zberzynie w grobowcu I zarejestrowano regularne smugi spalenizny z węgielkami, będące najprawdopodobniej śladami po dranicach (Gorczyca 2007, s. 6). W poszczególnych przypadkach trudno ustalić przyczyny pożaru omawianych budowli (Gorczyca, 1981, s. 18).

Można wskazać na co najmniej kilka przyczyn pożaru. Jedną z nich jest pożar przypadkowy - budowla zajęła się od znajdującego się wewnątrz niej ogniska/pale- 
Tabela 2. Ślady używania ognia w „domach kultowych” ludności kultury pucharów lejkowatych

Table 2. Traces of fire usage in cult houses of TRB

\begin{tabular}{|c|c|c|c|c|c|}
\hline \multirow[b]{2}{*}{ L.p. } & \multirow{2}{*}{$\begin{array}{l}\text { Miejscowość, } \\
\text { stanowisko nr }\end{array}$} & \multirow{2}{*}{$\begin{array}{l}\text { Numer } \\
\text { grobowca }\end{array}$} & \multicolumn{3}{|c|}{ Ślady używania ognia } \\
\hline & & & $\begin{array}{l}\text { ognisko / } \\
\text { palenisko }\end{array}$ & \begin{tabular}{|c|} 
pozostałości spalonych \\
„domów kultowych”
\end{tabular} & $\begin{array}{c}\text { inne ślady } \\
\text { używania ognia }\end{array}$ \\
\hline 1 & Broniszowice, stan. 5A & brak numeru & $\mathrm{X}$ & - & - \\
\hline 2 & Gaj, stan. 1 & 1 & - & $\mathrm{X}$ & - \\
\hline 3 & Karmanowice, stan. 35 & $\mathrm{~V} / 96$ & - & - & - \\
\hline \multirow{3}{*}{4} & \multirow{3}{*}{ Leśniczówka, stan. 1} & 1 & - & - & $\mathrm{X}$ \\
\hline & & 2 & - & $\mathrm{X}$ & - \\
\hline & & 3 & - & $\mathrm{X}$ & - \\
\hline 5 & Łącko, stan. 6-6A & 2 & $\mathrm{X}$ & $\mathrm{X}$ & - \\
\hline \multirow{2}{*}{6} & \multirow{2}{*}{ Malice Kościelne, stan. 1} & 1 & - & - & - \\
\hline & & 2 & - & - & - \\
\hline 7 & Obałki, stan. 1 & 2 & $\mathrm{X}$ & $\mathrm{X}$ & $\mathrm{X}$ \\
\hline \multirow{3}{*}{8} & \multirow{3}{*}{ Pawłów, stan. 3} & megalit & - & - & $\mathrm{X}$ \\
\hline & & „rów podkowiasty” & - & - & - \\
\hline & & budowla słupowa & - & - & - \\
\hline \multirow{2}{*}{9} & \multirow{2}{*}{ Sarnowo, stan. 1} & 8 & - & $\mathrm{X}$ & - \\
\hline & & 9 & - & - & - \\
\hline \multirow{2}{*}{10} & \multirow{2}{*}{ Wietrzychowice, stan. 1} & 3 & - & - & $\mathrm{X}$ \\
\hline & & 5 & - & - & - \\
\hline \multirow{2}{*}{11} & \multirow{2}{*}{ Zberzyn, stan. 3} & 1 & $\mathrm{X}$ & $\mathrm{X}$ & - \\
\hline & & 4 & - & $\mathrm{X}$ & - \\
\hline 12 & Zberzynek, stan. 4 & brak numeru & - & $\mathrm{X}$ & - \\
\hline
\end{tabular}

niska. „Dom kultowy” mógł być także podpalony celowo, ponieważ przestał pełnić już swe funkcje i stał się bezużyteczny. Należy również rozważyć możliwość jego umyślnego podpalenia, np. przez obcą, wrogo nastawioną grupę ludzi (Chmielewski 1952, s. 91), a także pożar spowodowany czynnikami naturalnymi (np. uderzenie pioruna, samozapłon), choć obie te sytuacje wydają się mało prawdopodobne.

W myśl interpretacji Andrzeja Pelisiaka (2006, s. 110-112) ślady palenia ognisk (,wielkich ogni”) w grobowcach megalitycznych mogą być symbolicznym nawiązaniem do podstawowych czynności rolniczych. W szczególności chodzi o przygotowywanie pól (wypalanie pierwotnej roślinności). Ślady świadczące o gospodarce wypaleniskowej stwierdzono na stanowisku w Zberzynie (Gorczyca 2007, s. 3). Następnie prawdopodobnie zbudowano grobowiec I - w trakcie badań odkryto w nim pozostałości spalonej budowli (Gorczyca 2007, s. 6). Można przypuszczać, że na stanowisku w Zberzynie mamy do czynienia ze śladami rozbudowanych praktyk pogrzebowych. Podobne czynności zostały zarejestrowane na stanowisku nr 5 w Broniszowicach. Według J.T. Bąbla (2006, s. 281) „teren pod budowę grobowca 
został oczyszczony ogniem, spalono całą roślinność porastającą wybrane miejsce. Śladem tej czynności, prócz wyraźnej ciemnej warstwy z węgielkami drzewnymi i polepą, jest także ognisko nr 1, zlokalizowane w SE narożniku grobowca, pod kamienną obstawą".

Możliwy jest także pożar będący elementem obrzędów pogrzebowych. Po zakończeniu już tzw. obrzędów przejścia czy po wykorzystaniu miejsca na grzebanie kolejnych zmarłych owa budowla w czole grobowca została podpalona (Chmielewski 1952, s. 91; Jażdżewski 1970a, s. 27; 1970b, s. 65). Ostatnia z wymienionych powyżej przyczyn pożaru „chat kultowych” wydaje się wysoce prawdopodobna. Jednak nie można wykluczyć pozostałych.

Pożar „domu kultowego” mógł stanowić element finalny obrzędów pogrzebowych. Stosowanie ognia w megalitycznym obrządku pogrzebowym KPL często miało symbolizować ognisko domowe: rozpalając je, pogrążeni w smutku bliscy nawiązywali kontakt ze zmarłym. Ogień jednoczył bliskich, a na czas pogrzebu symbolizował odradzające się życie. Być może dlatego podpalono „domy kultowe”, w których poprzez doczesne dobrodziejstwa żegnano się ze zmarłym. Ogień był zatem integralną częścią odprawianych obrzędów (Socha 2011, s. 61). Podpalenie omawianych obiektów mogło być również symbolicznym nawiązaniem do podstawowych czynności rolniczych wykonywanych w trakcie przygotowywania pól gospodarka wypaleniskowa ludności KPL (Pelisiak 2006, s. 112).

\section{UWAGI O FUNKCJI „DOMÓW KULTOWYCH”}

Budowle te sytuowane w czołach grobowców megalitycznych traktuje się zasadniczo jako „domy dla zmarłych” - taką ewentualność sugerują analogie z Danii (Madsen 1979, s. 306-310; Midgley 1985, s. 152-161). Omawiana funkcja najlepiej czytelna jest w przypadku „domów typu B”, ponieważ zbudowane one zostały bezpośrednio nad grobem/grobami zmarłych pogrzebanych w megalitach (ryc. 6). Można więc przypuszczać, że „domy kultowe typu B” zostały wzniesione niewątpliwie dla pochowanych pod nimi zmarłych, a bliscy zmarłego odprawiali w nich czynności obrzędowo-sakralne (Chmielewski 1952, s. 18-19, 34; Wierzbicki 2006, s. 90-91). A. Pelisiak (2006, s. 112-113) porównuje budynki mieszkalne ludności KPL $\mathrm{z}$ obiektami wzniesionymi $\mathrm{w}$ grobowcach megalitycznych. Twierdzi, że interpretowanie grobu jako „domu zmarłego" wydaje się oczywiste. $Z$ jego analizy wynika, iż są wyraźne podobieństwa w zakresie kształtu i wielkości domów na osadach KPL i konstrukcji drewnianych w obrębie grobowców (Pelisiak 2006, s. 108-113).

W kilku przypadkach „domy kultowe” mogły istnieć jeszcze jakiś czas po zakończeniu budowy nasypu grobowca (Gorczyca 1981, s. 18; 2007, s. 6-8). Można więc pokusić się o wysunięcie hipotezy, że prawdopodobnie pełniły one funkcje nie tylko funeralne i obrzędowo-sakralne, lecz także użytkowe. Obiekty te mogły służyć 
jako np. schronienie dla budowniczych przed niekorzystnymi warunkami atmosferycznymi. W takim wypadku nie miałyby charakteru kultowego. Pośrednim dowodem na to jest nagromadzenie licznych potłuczonych naczyń i kości zwierzęcych, jak również w niektórych przypadkach obecność palenisk w obrębie tych budowli (ryc. 5). Jak zauważa A. Pelisiak (2006, s. 110): „odpady odkryte w grobowcach mają generalnie »osadowy « charakter". Należy je łączyć z rytualnym przygotowywaniem i spożywaniem pokarmów, co mogło odbywać się także podczas budowy grobowca megalitycznego (Chmielewski 1952, s. 18). Obrzędy tego rodzaju niewątpliwie były również odprawiane po zakończeniu budowy megalitu. K. Jażdżewski (1936a) liczne nagromadzenie materiału zabytkowego i obecność ognisk-śmietnisk (Leśniczówka) uważał za swoisty rodzaj wynagrodzenia za podjęty trud dla budowniczych grobowca. W. Chmielewski (1952, s. 18) wskazuje na dłuższe użytkowanie tych obiektów (Leśniczówka, Obałki, Wietrzychowice) w trakcie budowy grobowca. Zdaniem J.T. Bąbla (2006, s. 284) cyklicznie obrzędy pogrzebowe (stypy) odbywały się w Broniszowicach. Ich pozostałością były potłuczone naczynia i wytwory krzemienne.

Niektórzy badacze interpretują megality jako słupy graniczne i swoiste drogowskazy (np. Wierzbicki 2006, s. 92-94). W odniesieniu do tej hipotezy można się zastanowić, czy „domy kultowe” po zakończeniu obrzędów związanych z pogrzebem zmarłego nie pełniły funkcji pomieszczeń dla „strażników”. Przez pojęcie „strażnik” rozumiemy osobę czuwającą nad spokojem zmarłego i jednocześnie dbającą o bezpieczeństwo granicy terytorium eksploatowanego przez daną grupę ludzi. Funkcje „strażnic” mogły pełnić zarówno „domy kultowe typu A”, jak i „typu B”. Pośrednim dowodem na taką interpretację mogą być liczne w tych obiektach fragmenty potłuczonych naczyń, kości zwierzęcych i wytworów krzemiennych. Sugeruje to wielokrotne ich używanie. Podobnie można wytłumaczyć zwyczaj palenia ognia przed lub w pobliżu omawianych „domów”. Cykliczne rozpalanie ogniska stwierdzono na stanowisku w Broniszowicach (Bąbel 2006, s. 284) (ryc. 8). Ognisko mogło być swoistą „latarnią”, punktem orientacyjnym wskazującym drogę. Nad tym, aby ogień nie wygasł, czuwali strażnicy (Ballenstedt 2000, s. 74-76).

Grobowce megalityczne lokowano często w miejscach eksponowanych (Chmielewski 1952, s. 19). Przykładowo: grobowce w Broniszowicach wyraźnie dominują nad bezpośrednim otoczeniem. Doskonale widoczne są stanowiska VII (grobowce) i IX (osada neolityczna) w Stryczowicach (Iwaniszewski 2006, s. 262). Można więc zaryzykować hipotezę o komunikacyjnej funkcji ognisk rozpalanych na tych stanowiskach. Obecność ogniska przed grobowcem w Broniszowicach czyni ją prawdopodobną. „Sygnały dymne” wysyłane przez ogniska mogły ułatwiać kontakt pomiędzy poszczególnymi osadami. Być może również ostrzegały przed niebezpieczeństwem.

Podsumowując powyższe rozważania dotyczące funkcji „domów kultowych”, należy stwierdzić, że były one „domami zmarłych” i poza główną funkcją „kultową”, 
mogły pełnić wiele innych funkcji obrzędowo-sakralnych. Nie można jednak zapominać przy tym o możliwościach utylitarnego wykorzystania tych obiektów. Choć w głównej mierzy wynika to bardziej z „chciejstwa” badaczy niż uzasadnionych naukowo dowodów.

\section{ANALOGIE}

Obiekty podobne do „domów kultowych” zostały zarejestrowane podczas badań archeologicznych m.in. w Danii oraz Anglii. Ich problematyka została szeroko omówiona m.in. w pracach Stuarta Piggotta (1967), Konrada Jażdżewskiego (1970a, 1970b), Torstena Madsena (1979) czy Magdaleny S. Midgley (1985).

W Danii (np. w Barkaer, Bygholm Nørremark, Tustrup, Ferslev, Herrup, Foulum, Engedal, Nørre Onsild oraz na wyspie Sejerø koło Zelandii) praktyki obrzędowe na cmentarzyskach KPL odbywano w specjalnych, osobno stojących, dość dużych budynkach drewnianych, określanych w literaturze przedmiotu również jako „domy kultowe” (Jażdżewski 1981, s. 210; Krzak 1994, s. 233-235; Madsen 1979, s. 306-310; tam starsza literatura). Podobne do nich obiekty odkryto również w Anglii południowej, np. Nutbane, Hampshire, Wayland's Smithy w Berkshire oraz Fussell's Lodge w Wiltshire (Piggott 1967, s. 383-388). Prawdopodobnie służyły one celom obrzędowo-sakralnym związanym z pogrzebem zmarłego.

„Domy kultowe” z ziem polskich w rzucie poziomym najczęściej miały kształt kwadratowy, prostokątny lub zbliżony do trapezu, rzadziej owalny. Podobny kształt miały obiekty z obszarów Danii i południowej Anglii. Wymiary „domów kultowych" z obszarów Polski zbliżone są także do obiektów duńskich i angielskich. Rozmiary budowli odkrywanych w Polsce wahają się od 6,5 × 8,0 m (Łącko), poprzez 4,5 × 4,5 m (Leśniczówka, grobowiec $\mathrm{nr} 2$ ) do 2,3 × 1,7 m (Leśniczówka, grobowiec $\mathrm{nr} 1$ ). Natomiast rozmiary konstrukcji z Danii wynoszą przeważnie ok. $6 \times 6 \mathrm{~m}$, $6 \times 5 \mathrm{~m}$ lub $5 \times 4 \mathrm{~m}$. Tylko na Sejerø budowla owalna była nieco większa - ok. $10 \times 6 \mathrm{~m}$ (Krzak 1994, s. 233-235). Z kolei rozmiary obiektów z Anglii wahają się od 4,0 × 2,5 m do 6,0 × 5,5 m (Piggott 1967, s. 383-388).

„Domy kultowe” $\mathrm{z}$ terenu Polski wznoszone były w kilku technikach konstrukcyjnych: sumikowo-łątkowej, zrębowej lub w technice opisanej przez J.T. Bąbla (2006, s. 282-283). Według badaczy konstrukcja ścian i dachu była różna. Przypuszczają, że dach najczęściej był konstrukcją dwuspadową wspartą na słupach, rzadziej czterospadową. Ściany omawianych obiektów z Danii budowano czasem $\mathrm{z}$ drewnianych słupów bądź belek czy dranic umieszczonych w rowie fundamentowym ze wzmocnieniami i uszczelnieniami z kamieni. W Lindebjerg odkryto dwie drewniane komory wykonane $\mathrm{z}$ dranic, $\mathrm{z}$ płaskim lub dwuspadowym dachem. Znajdowały się one w kamiennym 48-metrowym „łożu” (Madsen 1979, s. 308, fig. 4c). 
Najczęściej jednak „domy kultowe” zbudowane były w technice zrębowej, z dachem dwuspadowym wspartym na sochach i ślemieniu. Czasami dodatkowo uszczelniano je gliną. Pierwotną wysokość ścian ocenia się na ponad $2 \mathrm{~m}$. W obiektach tych zanotowano dużą liczbę naczyń, groty strzał i pojedyncze siekiery złożone tam w ofierze (Jażdżewski 1981, s. 10; Krzak, 1994, s. 233-235).

Jamy odkryte w „domach” w Obałkach, Gaju i Leśniczówce (Jażdżewski 1936a, s. 172-182; Chmielewski, 1952, s. 73-92) mają analogie w Tustrup, gdzie pośrodku „domu kultowego" zarejestrowano jamę wypełnioną piaskiem, a wokół niej sporo fragmentów naczyń (Krzak 1994, s. 234). Zapewne takie jamy pełniły bliżej nieokreślone funkcje obrzędowo-kultowe. Mogły to być na przykład miejsca składania ofiar.

Na ziemiach polskich ogniska w „domach kultowych” zarejestrowano w Broniszowicach (Bąbel 2006, s. 273, 284, ryc. 4), Łącku (Domańska 2006, s. 289-298) czy Zberzynie (Gorczyca 2007, s. 7). Podobne obiekty odkryto w Ferslev, gdzie wewnątrz „domu kultowego" odkryto podłużne czterometrowe ognisko otoczone kamieniami; tuż przed wejściem znajdowało się drugie mniejsze ognisko (Krzak 1994, s. 234). W Herrup na zgliszczach „domu” położono bruk kamienny o wymiarach $11 \times 9$ m (Krzak 1994, s. 235). Na obszarze Danii szczątki zmarłych KPL wykazują ślady działania ognia i często przykryte są rumoszem ze spalonych konstrukcji „domów kultowych”. Dopiero nad tymi zgliszczami rozpoczynano budowę nasypu (Krzak 1994, s. 227). Na szczątkach kostnych jednego z osobników pochowanych $\mathrm{w}$ grobie centralnym grobowca trapezowatego w Pawłowie również zaobserwowano ślady działania ognia (Zychman-Kozak, Szeliga 2005, s. 36).

Interesujące jest to, iż wszystkie „domy kultowe” odkryte w Danii zostały spalone (Jażdżewski 1981, s. 210; Krzak 1994, s. 232-234). Prawdopodobne przyczyny pożaru mogły być różne (szczegółowo zostały omówione wyżej). Ślady palenia ognia zarejestrowano również w konstrukcjach wzniesionych na obszarze Anglii południowej (Jażdżewski 1970a, s. 27; Piggott 1967, s. 383-388). Na obszarze Polski tego typu pozostałości znaleziono w Gaju, Leśniczówce, Łącku, Obałkach, Sarnowie, Zberzynie i Zberzynku (?). Stanowiska te znajdują się na Kujawach i we wschodniej Wielkopolsce, w zasięgu grupy wschodniej KPL. Na obszarze grupy południowo-wschodniej dotychczas nie stwierdzono obecności spalonych „domów kultowych" (Socha 2011, s. 60).

Powyższe analogie wskazują, że obecność „domów kultowych” w grobowcach KPL na ziemiach polskich nie była niczym wyjątkowym i analogiczne obiekty występują w całej kulturze pucharów lejkowatych. Podobieństwa odnajdujemy w lokalizacji „domów”, konstrukcji ścian czy dachu, obecności obiektów towarzyszących (jamy, paleniska), czy wreszcie pożarach „domów”. Paralele dotyczą także funkcji tych obiektów. „Domy kultowe” w ramach całej kultury pucharów lejkowatych traktuje się zasadniczo jako „domy dla zmarłych”. 


\section{ZAKOŃCZENIE}

Niniejszy artykuł stanowi podsumowanie dotychczasowego stanu wiedzy na temat tzw. domów kultowych odkrywanych w megalitycznym obrządku pogrzebowym ludności KPL w grupie wschodniej i południowo-wschodniej.

Zaproponowany podział „domów kultowych” na typy „A” i „B” wydaje się lepiej je charakteryzować. Warto również zwrócić uwagę na reinterpretację niektórych obiektów na budowle tego typu, pozwalającą na znaczące zwiększenie ich liczby. Jeśli obrany kierunek interpretacji jest trafny, może to oznaczać, że obecność konstrukcji drewnianych w grobowcach KPL na ziemiach polskich nie była niczym wyjątkowym. Niewykluczone przy tym, że obiekty te mogły pełnić funkcje nie tylko sakralno-obrzędowe.

Na zakończenie naszych rozważań warto zacytować Szanowną Jubilatkę, Panią Profesor Dobrochnę Jankowską (2009-2010, s. 271), która w taki sposób charakteryzuje obrządek pogrzebowy ludności kultury pucharów lejkowatych: „obowiązujący rytuał ograniczał się do formy właściwego grobu i pochówku, z licznymi zresztą wyjątkami od reguły, i, zapewne, do odpowiednich, nie zawsze możliwych do identyfikacji archeologicznej, obrzędów towarzyszących”. W innym miejscu swojego tekstu D. Jankowska pisze: „nie można jednak oprzeć się wrażeniu, że w porównaniu z innymi aspektami swojej kultury, które nie mają tak »rewolucyjnego« charakteru, ludność KPL wykazywała w dziedzinie rozwoju duchowego ponadprzeciętną kreatywność i samodzielność” (Jankowska, 2009-2010, s. 272).

Zagadnienie różnorodności „domów kultowych” oraz poglądów na ich funkcje wymaga jednak dalszych studiów i fachowego opracowania. Trwające badania wykopaliskowe na niektórych stanowiskach w Polsce mogą dostarczyć nowych materiałów źródłowych. Priorytetem (w szczególności dla grupy południowo-wschodniej) w badaniach nad ,domami kultowymi” jest ustalenie ich chronologii. Ponadto otwarta pozostaje problematyka genezy tych obiektów. Tutaj należałoby się odnieść do kwestii megaksylonów. Istotne w moim odczuciu wydaje się ustalenie zależności chronologicznej pomiędzy nimi a „domami kultowymi”.

\section{BIBLIOGRAFIA}

Bargieł B., Florek M.

2002 Zespół grobowo-kultowy ludności kultury pucharów lejkowatych w Pawłowie koło Zawichostu (stanowisko 3) w świetle badań wykopaliskowych w latach 1999-2001.

Bargieł B., Florek M. Zeszyty Sandomierskie, 15, s. 28-31.

2005 Wyniki badań wykopaliskowych prowadzonych w latach 2001-2003 na cmentarzysku kultury pucharów lejkowatych w Pawłowie, stan. 3, pow. Sandomierz. Archeologia Polski Środkowowschodniej, 7, s. 20-32. 
Bargieł B., Florek M.

2006a Cmentarzysko ludności kultury pucharów lejkowatych na stanowisku $1 \mathrm{w}$ Malicach Kościelnych, pow. Opatów. W: J. Libera, K. Tunia (red.), Idea megalityczna w obrządku pogrzebowym kultury pucharów lejkowatych (s. 361-384). Lublin-Kraków: Instytut Bargieł B., Florek M.

Archeologii PAN, Oddział w Krakowie, Instytut Archeologii UMCS w Lublinie.

2006b Cmentarzysko w Pawłowie na tle innych podobnych stanowisk kultury pucharów lejkowatych. W: J. Libera, K. Tunia (red.), Idea megalityczna w obrządku pogrzebowym kultury pucharów lejkowatych (s. 385-400). Lublin-Kraków: Instytut Archeologii PAN, Oddział w Krakowie, Instytut Archeologii UMCS w Lublinie.

Bargieł B., Florek M., Libera J.

1999 Trzeci sezon badań wykopaliskowych na stanowisku 1 w Malicach Kościelnych, pow.

Bąbel J.T. Opatów, woj. Świętokrzyskie. Archeologia Polski Środkowowschodniej, 4, s. 29-37.

2006 Próba rekonstrukcji grobowca megalitycznego ze stanowiska V w Broniszowicach, pow. Ostrowiec Świętokrzyski. W: J. Libera, K. Tunia (red.), Idea megalityczna w obrządku pogrzebowym kultury pucharów lejkowatych (s. 271-288). Lublin-Kraków: Instytut Archeologii PAN, Oddział w Krakowie, Instytut Archeologii UMCS w Lublinie.

Ballenstedt J.

2000 Architektura. Historia i teoria. Warszawa-Poznań: Wydawnictwo Naukowe PWN.

Burchard B.

$1973 \quad$ Z badań neolitycznej budowli trapezowatej w Niedźwiedziu, pow. Miechów (stan. 1). Sprawozdania Archeologiczne, 25, s. 39-48.

Burchard B.

1998 Badania grobowców typu megalitycznego w Zagaju Stradowskim w południowej Polsce. Sprawozdania Archeologiczne, 50, s. 149-155.

Burchard B.

2006 Grobowce typu megalitycznego w Zagaju Stradowskim, pow. Kazimierza Wielka. W:

J. Libera, K. Tunia (red.), Idea megalityczna w obrzadku pogrzebowym kultury pucharów lejkowatych (s. 301-305). Lublin-Kraków: Instytut Archeologii PAN, Oddział w Krakowie, Instytut Archeologii UMCS w Lublinie.

Chmielewski W.

1952 Zagadnienia grobowców kujawskich w świetle ostatnich badań. Łódź: Wydawnictwo Muzeum Archeologicznego w Łodzi.

Cholewa P., Wojciechowski W., Limisiewicz A.

2003 Drugi sezon badań wykopaliskowych na megalitycznym cmentarzysku kultury pucharów lejkowatych w Muszkowicach, stan. 18, pow. Ząbkowice Śląskie. Śląskie Sprawozdania Archeologiczne, 45, s. 119-124.

Cholewa P., Wojciechowski W., Limisiewicz A.

2004 Badania wykopaliskowe na megalitycznym cmentarzysku kultury pucharów lejkowatych w Muszkowicach w roku 2003 (pow. Ząbkowice Śląskie), Śląskie Sprawozdania Archeologiczne, 46, s. 43-51.

Domańska L.

1995 Geneza krzemieniarstwa kultury pucharów lejkowatych na Kujawach. Łódź: Instytut Archeologii i Etnologii Polskiej Akademii Nauk.

Domańska L.

2006 Cmentarzysko megalityczne kultury pucharów lejkowatych w Łącku, pow. Inowrocław.

W: J. Libera, K. Tunia (red.), Idea megalityczna w obrzadku pogrzebowym kultury pu- 
charów lejkowatych (s. 289-298). Lublin-Kraków: Instytut Archeologii PAN, Oddział w Krakowie, Instytut Archeologii UMCS w Lublinie.

Florek M.

2008 Cmentarzyska kultury pucharów lejkowatych na Wyżynie Sandomierskiej. Historia i stan badań. Wiadomości Archeologiczne, 60, s. 97-123.

Gabałówna L.

1968 Sprawozdanie z prac wykopaliskowych w Sarnowie, pow. Włocławek, przeprowadzonych w roku 1967 na stanowiskach 1 i 1A. Prace i Materiały Muzeum Archeologicznego i Etnograficznego w Lodzi. Seria Archeologiczna, 15, s. 135-147.

Gorczyca K.

1981 Grobowiec kujawski w Zberzynie, woj. konińskie. Fontes Archaeologici Posnanienses, 30, s. $1-20$.

Gorczyca K.

2007 Sprawozdanie z archeologicznych wykopaliskowych badań ratunkowych przeprowadzonych w Zberzynie, gm. Kleczew, powiat Konin, woj. wielkopolskie, na stanowisku 3, AZP 52-39/3. Grobowiec I. [Maszynopis sprawozdania w archiwum Wielkopolskiego Wojewódzkiego Konserwatora Zabytków, oddział Konin].

Iwaniszewski S.

2006 Megalityczny obrządek pogrzebowy i neolityczny krajobraz w mikroregionie stryczowickim na Wyżynie Sandomiersko-opatowskiej. W: J. Libera, K. Tunia (red.), Idea megalityczna w obrządku pogrzebowym kultury pucharów lejkowatych (s. 259-269). Lublin-Kraków: Instytut Archeologii PAN, Oddział w Krakowie, Instytut Archeologii UMCS w Lublinie.

Jadczykowa I.

1970 Sprawozdanie z badań przeprowadzonych w latach 1967 i 1968 na stanowisku w Wietrzychowicach, pow. Koło. Prace i Materiały Muzeum Archeologicznego i Etnograficznego w Łodzi. Seria Archeologiczna, 17, s. 125-143.

Jadczykowa I.

1972 Sprawozdanie z końcowego etapu prac badawczych na neolitycznym cmentarzysku grobowców kujawskich w Wietrzychowicach, pow. Koło. Prace i Materiały Muzeum Archeologicznego i Etnograficznego w Łodzi. Seria Archeologiczna, 18(1971), s. 93-103.

Jankowska D.

2005 O pochodzeniu pomorskich grobowców bezkomorowych kultury pucharów lejkowatych. Folia Praehistorica Posnaniensia, 13, s. 133-144.

Jankowska D.

2009-2010 W kwestii obrządku pogrzebowego KPL na ziemiach polskich - stare i nowe problemy. Sborník praci Filozofické fakulty brněnské univerzity. M, ̌̌ada archeologická, 58-59, s. $263-275$.

Jastrzębski S., Ślusarska M.

1982 Grobowce kultury pucharów lejkowatych z Lublina-Sławinka i Miłocina-Kolonii, woj. lubelskie. Wiadomości Archeologiczne, 47(2), s. 191-229.

Jażdżewski K.

1936a Kultura puharów lejkowatych w Polsce zachodniej i środkowej. Poznań: Polskie Towarzystwo Prehistoryczne.

Jażdżewski K.

1936b Olbrzymi grób kujawski w Wietrzychowicach. Z Otchlani Wieków, 11, s. 121-129.

Jażdżewski K.

1970a Związki grobowców kujawskich w Polsce z grobami megalitycznymi w Niemczech północnych, w Danii i w krajach zachodnioeuropejskich. Prace i Materiały Muzeum Archeologicznego i Etnograficznego w Lodzi. Seria Archeologiczna, 17, s. 15-48. 
Jażdżewski K.

1970b Wzajemny stosunek do siebie elementów północnych, południowych i zachodnich w obrębie kultury pucharów lejkowatych. Prace i Materiały Muzeum Archeologicznego i Etnograficznego w Łodzi. Seria Archeologiczna, 17, s. 49-76.

Jażdżewski K.

1981 Pradzieje Europy Środkowej. Wrocław: Zakład Narodowy im. Ossolińskich.

Kośko A.

1976 Przyczynek do badań nad kujawską enklawą tzw. „grobowców bezkomorowych”. Archeologia Polski, 21(2), s. 402-408.

Kozak-Zychman W., Szeliga M.

2005 Pochówki z cmentarzyska ludności kultury pucharów lejkowatych w Pawłowie, stan. 3, pow. Sandomierz (Badania 2001-2003 r.). Archeologia Polski Środkowowschodniej, 7, s. 33-41.

Kozłowski L.

1921 Groby megalityczne na wschód od Odry. Kraków: nakładem Polskiej Akademii Umiejętności.

Krzak Z.

1994 Megality Europy. Warszawa: Wydawnictwo Naukowe PWN.

Madsen T.

1979 Earthen Long Barrows and Timber Structures. Aspects of the Early Neolithic Mortuary

Practice in Denmark. Proceedings of the Prehistoric Society, 45, s. 301-320.

Midgley M.S.

1985 The origin and function of the earthen long barrows of northern Europe. British Archaeological Reports, 259. Oxford: British Archaeological Reports.

Niesiołowska-Śreniowska E.

1982 Materiały krzemienne z fazy AB kultury pucharów lejkowatych z grobowca $8 \mathrm{w}$ Sarnowie w woj. włocławskim. Prace i Materiały Muzeum Archeologicznego i Etnograficznego w Lodzi. Seria Archeologiczna, 27(1980), s. 85-155.

Nogaj-Chachaj J.

1991 The stone-packed graves of the Funnel Beaker culture in Karmanowice, site 35. Antiquity, 65(248), s. 628-640.

Nogaj-Chachaj J.

1997 Dziewiąty sezon badań na stanowisku 35 w Karmanowicach, woj. Lubelskie. Archeolo-

Nogaj-Chachaj J. gia Polski Środkowowschodniej, 2, s. 16-23.

1998 Dziesiąty sezon badań cmentarzyska i osady KPL na stanowisku 35 w Karmanowicach,

Pelisiak A. woj. Lubelskie. Archeologia Polski Środkowowschodniej, 3, s. 30-35.

2006 Grobowce megalityczne. Nowe możliwości interpretacji? W: J. Libera, K. Tunia (red.), Idea megalityczna w obrządku pogrzebowym kultury pucharów lejkowatych (s. 103-116). Lublin-Kraków: Instytut Archeologii PAN, Oddział w Krakowie, Instytut Archeologii UMCS w Lublinie.

Piggott S.

1967 „Unchamberet” long barrows in Neolithic Britain. Paleohistoria, 12(1966), s. 381-393.

Rzepecki S.

2004 Spoleczności środkowoneolitycznej kultury pucharów lejkowatych na Kujawach. Poznań: Wydawnictwo Poznańskie. 
Rzepecki S. 2011

Socha K. 2011

Tetzlaff W.

1961 Grobowce kultury pucharów lejkowatych ze Zberzynka, pow. Konin i Obałek, pow.

Tunia K.

1996

Tunia K. 2003a

Tunia K. 2003b

Tunia K. 2006

Wierzbicki J. 1999

Wierzbicki J.

2006 Megality kultury pucharów lejkowatych - czy tylko grobowce? W: J. Libera, K. Tunia (red.), Idea megalityczna $w$ obrzadku pogrzebowym kultury pucharów lejkowatych (s. 87-101). Lublin-Kraków: Instytut Archeologii PAN, Oddział w Krakowie, Instytut Archeologii UMCS w Lublinie.

Wierzbicki J. 2008

Wiklak H. 1975

Wiklak H. 1982

Wiklak H.

Neolit Wielkopolski w świetle ostatnich badań. W: H. Machajewski (red.), Wielkopolska $w$ dziejach. Archeologia o regionie (s. 31-55). Poznań: Stowarzyszenie Naukowe Archeologów Polskich.

Wyniki badań wykopaliskowych na grobowcu 9 w Sarnowie, pow. Włocławek. Sprawozdania Archeologiczne, 27, s. 43-53.

1986 Wyniki badań wykopaliskowych w osadzie i na cmentarzysku kultury pucharów lejkowatych na stanowisku 1A w Sarnowie, woj. włocławskie. Prace i Materiały Muzeum Archeologicznego i Etnograficznego w Lodzi. Seria Archeologiczna, 30, s. 167-191. 
Zych R.

2002 Wielkie domostwa i grobowce typu kujawskiego w kulturze symbolicznej neolitu na zie-

Zych R. miach polskich. Rzeszów: Instytut Archeologii Uniwersytetu Rzeszowskiego.

2006 Organizacja przestrzeni miejsc z grobowcami kujawskimi i jej symbolika. W: J. Libera, K. Tunia (red.), Idea megalityczna w obrządku pogrzebowym kultury pucharów lejkowatych (s. 117-126). Lublin-Kraków: Instytut Archeologii PAN, Oddział w Krakowie, Instytut Archeologii UMCS w Lublinie.

\title{
SO-CALLED CULT HOUSES IN MEGALITHIC TRADITIONS \\ OF THE FUNNEL BEAKER CULTURE IN POLAND
}

\author{
Su m mary
}

There are several terms used in literature to refer to wooden structures discovered in megaliths built by the TRB populations, including: cult buildings, cult houses or small cult houses, temples, sanctuaries, chapels, wooden structures, and also cult huts (e.g. Bush 1994; Chmielewski 1952; Madsen 1979; Midgley 1985; Mustard 1981; Rzepecki 2011; Wierzbicki 2006, 2008; Zych 2002, 2006). For the purpose of this article, the term cult houses is accepted, as, according to the author, it describes best the nature, construction and function of these structures.

The chronological framework adopted in this paper refers to the period from the beginning of the Sarnów phase (A/B) in Kujawy (Rzepecki 2004, p. 98, Tab. 18; Wiklak 1982, p. 65) until the transformation and disappearance of the Lupawa group (Wierzbicki 1999, p. 11). However, one should be aware of the fact, that suggested chronology might be verified and altered as a result of new archaeological investigations and the results of specialised analyses of evidence already collected.

The study area has been confined to the Polish territory. The constructions discussed in the article were used in funeral rites of the populations of the Eastern and South-Eastern groups of TRB (Fig. 1). However, for the purpose of interpretation, analogies from neighbouring areas (Southern and Northern groups of TRB) have been also included.

On the basis of the analysis of the location of "houses" in relation to burials at the front side of megaliths, cult houses might be divided into three types:

Type A - common feature of this type is their location at the front, usually the eastern, wider part of a barrow. This type is not placed above the TRB grave/graves. In most cases, in this front part of a megalith there is an entrance, enabling communication with the interior of a "house". Each of discussed structures is characterised by individual constructive features. They also differ in size. There were seven objects classified into this group (Tab. 1);

Type B - common feature of this type is their location within a megalith over TRB grave/graves. Each of discussed structures is characterised by individual constructive features. They also differ in size. (eight objects - Tab. 1);

Hypothetical cult houses - objects that are probably the remains of such buildings, but it is impossible to determine/specify their type (five objects - Tab. 1). 
The function of the objects is usually defined as "houses for the dead" - as illustrated by analogies from Denmark (Madsen, 1979, pp. 306-310; Midgley, 1985, pp. 152-161). This function is best recognisable in the case of "type B cult houses", because they were built directly over the grave/graves of the dead buried in megaliths. They might have been built for the dead buried underneath, and their relatives might have celebrated there their ritual and religious activities (Chmielewski, 1952, pp. 18-19, 34; Wierzbicki, 2006, pp. 90-91).

Various researchers suppose that these objects might have also served for utilitarian purposes, such as that of a shelter for megalith-builders in poor weather conditions. As observed by A. Pelisiak (2006, p. 110): "waste discovered in barrows generally has a 'household-like' character". Therefore, they might be linked with the ritual preparation and consumption of food, which could also take place during the construction of megaliths (Chmielewski 1952, p. 18).

Cult houses could have also been used by the "guards" - people taking care of peace for the dead, and at the same time of the security of the borders of the territory occupied by particular communities.

The above suggested division of the discussed structures into types " $A$ " and " $B$ " seems to provide their better characteristics. What is also worth noticing is that reinterpretation of some other features as buildings of this type, would cause a significant increase in their number. If the course of interpretation applied herein appears accurate, it may indicate that the presence of wooden structures in TRB megaliths within the Polish lands was nothing exceptional.

Translated by Lucyna Leśniak 